DOI https://doi.org/10.18551/rjoas.2017-01.08

\title{
IMPACT ANALYSIS OF SHOPPING AREA ON THE IMPROVEMENT OF EDUCATION AND INDEX HEALTH DISTRICTS IN SOUTH SUMATRA, INDONESIA
}

\author{
Pasrah Rudi, Susetyo Didik, Robiani Bernadette, Azwardi \\ University of Sriwijaya, Indonesia \\ ${ }^{*}$ E-mail: rudi.pasrah@gmail.com
}

\begin{abstract}
Monetary and economic crisis of 1997 has brought great changes in the life of society and the nation of Indonesia. In this period, GDP declined by $20 \%$ per year, the exchange rate becomes more than IDR 16,000 per US dollar and inflation almost approaching $100 \%$. Anticipating lowering economic consequences of the crisis, the government implemented the concept of regional autonomy in early 2001 through Act No. 22 year 2009 on local government and Act No. 25 Year 2009 on financial balance between central and local governments, as last amended by Act No. 23 year 2014 and Act No. 33 of 2004. The important implication of regional autonomy concept is fiscal decentralization that gives authority to local governments to regulate and manage their own governmental affairs in the Republic of Indonesia, which aims to improve the welfare of the community through a variety of measures of development success. UNDP set one of the measures of development success with the concept of HDI (Human Development Index). Indonesia is ranked 121 of 187 countries. Compared with the ASEAN countries, Indonesia is still ranked below the member countries of ASEAN. HDI differences between provinces and districts /cities still show the varied numbers. This study analyzes the impact of the district spending to the improvement of education index and health index as a component of IPM, the total expenditure and the GDP impact to the IPM and analyze the impact of the balance funds to the GDP. The analysis showed a significant relationship between exogenous and endogenous variables in four models were formed and the characteristics of each district / city.
\end{abstract}

\section{KEY WORDS}

Fiscal decentralization, spending, education index, health index, human development index.

Monetary and economic crisis that occurred in Indonesia in 1997 has brought a tremendous change in all aspects of society and the nation of Indonesia. More broadly, as a result of the economic and monetary crisis even threaten the sustainability of the Homeland. The crisis has led to the threat of disintegration areas in the State of Indonesia. The economic turmoil has led to regional attitudes and strong individualism even tend to lead to an attitude of opposition to higher government. Panic areas on the economic crisis has brought a great impact on the state cycle (Tambunan, 2012).

Noting the threat of disintegration is more pronounced and widespread, the Government and the House of Representatives (DPR) agreed to divide government functions that had been centralized to the power that is distributed to all regions through the system of regional autonomy even to the autonomy at the village level (Nurman, 2015). According Elsye (2013) theoretically in the context of a unitary state is known there are two ways to connect the central government and local governments are centralized and decentralized.

The starting point of the implementation of regional autonomy is the enactment of Law No. 22 of 1999 on local governance and Law No. 25 of 1999 on the financial balance between central and local governments. Kumorotomo (2008) states that the Act governs the fiscal decentralization between levels of government so that the division of authority becomes better and clearer. It is obviously in the sense that there is a fundamental assertion which the rights and obligations of the central government, which the rights and obligations of local governments both provincial and district / city. After the enactment of the Law on Local Government and Law on Financial Balance between Central and Local Government then 
commencing on January 1, 2001 implementation of the planned regional autonomy officially began to be implemented in Indonesia (Alisyahbana, 2000).

According to Abimanyu (2009) local autonomy was welcome with a variety of expectations and anxiety by all the people in the area. Most people in the region had a dream that regional autonomy would make society more prosperous, but not a few areas that worry because they realize the potential and the lack of available resources. The resource potential differences may lead to differences in economic growth in each region that will ultimately result in the level of welfare. In addition to the hopes and anxieties public, in the early stages of implementation of regional autonomy there is also a problem in terms of the fiscal. The regional autonomy policy has caused financial imbalances between the central government and local governments. Before more financial autonomy to a centralized interim central government after the regional autonomy era, more financial distributed to local governments. The situation ran only on the early stages and later the central government began to adjust the distribution pattern of the budget. Two years before the end of regional autonomy (1999) and the early years of the implementation of regional autonomy in Indonesia (2001) the percentage of the central government budget has decreased its portion from its previous state. After the implementation of regional autonomy in 2001 budget for the region increased by $2.16 \%$ of the Gross Domestic Product while central government expenditure decreased by $-1.69 \%$ from the Gross Domestic Product. Differences in the composition of the budget changes before and after decentralization, particularly to the amount of funds that was transfered by local governments had repercussions on the management of funds for the government.

Law governing regional autonomy will then undergo further refinement into Law Number 32 Year 2004 regarding Regional Government as amended into Law No. 23 of 2014 and Act No. 33 of 2004 on Financial Balance between the Central Government and Area. These enhancements related to ambivalence provinces as autonomous regions and administrative areas, bias rich regions in natural resources and there is no constitutional mechanism for communities to supervise the local government so that the chances of reemergence of abuse of power in wide areas open. Furthermore, there are two reasons why it is necessary to improve the Act, namely (1) the central government never seriously gives right of autonomy to the local government. The lack of seriousness can be seen from the omission of the central government on various legislations which are no longer in accordance with the Law The new autonomy even though there are hundreds of government regulations, presidential decrees and various other regulations that must be adjusted with an autonomy (Mungkasa, 2014).

In Act No. 23 of 2014 and Act No. 33 of 2004 stipulates three factors are fundamental, namely: (1) empowering potential of society, (2) foster initiative and creativity, (3) to enhance public participation actively and improve the role of the Regional Representatives Council. Act the local government there is an agenda for change that includes local authorities more clearly, increase community participation actively and constructively and more acceptance specified task.

Law on local government defines on autonomy as a right, power and obligation autonomous regions to set up and manage their own affairs and interests of local communities in accordance with the legislation. Referring to the autonomy normative definition of the area then there are three elements in the autonomous regions, namely: (1) The rights, (2) authority, (3) Obligations area. These three aspects are related to one another. There is a right areas given the authority to manage it well, but the other side also the obligations arising demands attention by the local government. These three elements can not be separated from each other. All three also have to go hand in hand in the development process.

One of the important implications that exist in the system of regional autonomy is fiscal decentralization. Kuncoro (1995) states that the growing attention to fiscal decentralization is caused by two things: (1) associated with the failure of centralized planning with a strategy of growth and distribution (2) the awareness that development is a process that is complex and full of uncertainty that can not be easily controlled and centrally planned. 
The delivery of such government affairs should also be followed by fiscal handover to the district / city. The nature of the relationship between local autonomy and fiscal decentralization is essentially a manifestation of the principle money follows function (Bahl, 1998), which means that the provision of duty and authority to local governments will be accompanied by the division of authority to the regions in terms of funding. Implementation of the handover of authority to the regions, then the given area sources of funding to exercise these powers. Rahmawati (2008) states that it is necessary given the setting such that expenditure needs are the responsibility of the regions can be financed from existing revenue sources. It should also be understood that the fiscal decentralization in Indonesia is the fiscal decentralization on the expenditure side which is funded mainly through transfer area. The essence of fiscal management in the region focused on the freedom to spend the funds according to the needs and priorities of each region, even so the area can not spend the fiscal transfer without clear rules and authority.

Learn more on fiscal decentralization, there are three main things that should be noted. First, the assumption is that the region is a major part of which will provide public services. Second, the complex relationship between the regions with the movement of people. Third, the financial distribution to each region taking into account the needs and the relationship between levels of government and relations with other regions. As the region is at the front lines to provide public services is certainly channeling funds are also intended to meet minimum service standards required by each sector of development.

According to Akhmad (2012) that the fiscal decentralization in Indonesia is characterized by increasing the allocation of transfers from central government to local governments as grants in the form of (1) an increase in the Fund (DBH) to the local government, (2) an increase in the General Allocation Fund (DAU) formerly known as autonomous regions of subsidies and the president's instructions, (3) an increase in the Special Allocation Fund (DAK). The number of transfer allocation is certainly expected by the central government can stimulate the economy in the area. Forms great attention from the central government to the amount of funds transfer delivered to the region is expected to strengthen the region's economic fundamentals as well as reducing the inequalities of the above development undertaken by each region.

Nanga (2006) analyzes a percentage of the amount of funds transfer both the General Allocation Fund (DAU), Special Allocation Fund (DAK) and DBH (DBH) were given to the region in a span of three years between 2001-2003 and found that the funds -Funds transfer give a large impact on revenues in the Budget revenue and Expenditure. If it is in the percentage and then contribute funds transfer ranged between 85-90 percent of the total budget. The percentage of fiscal transfers will certainly have a great impact on improving the welfare of the area included in moving the economy in order to increase local economic growth. The transfer of the percentage allocation for local finance will impact the region's financial stability. Still the magnitude of these portions can be interpreted that there are still many areas that do not have the independence in terms of local finance.

Besides these conditions also occur in conditions where the level of development of a region with other regions also experiencing inequality. Kuncoro (2013) states that the gravity of economic activity Indonesia still tend to be concentrated geographically to the western region of Indonesia for more than 5 decades. Imagine the BPS second quarter of 2012 showed the spatial structure of the Indonesian economy is still dominated by the Province on Java island which contributes to the Gross Domestic Product of about $57.5 \%$, followed by about $23.5 \%$ of Sumatra island, eastern Indonesia only gets the remaining approximately $19 \%$.

Such circumstances have led to differences in development between regions in Indonesia. One area has a good level of economic development and continues to increase but the other areas that have no small contribution has improved dramatically.

Susetyo (2004) in a study stating that (1) In the implementation of regional autonomy, particularly financial management has not been carried out properly so that the visible presence of the tug of authority between the center and regions (2) Pattern fiscal centralizitation foster strong dependence so that the creativity of the region to optimize the 
reception itself relatively low. (3) One of the principal balanced budget applied in the observation period of less spur regional economic growth. (4) The results of this study have implications for local finance current agenda at the prospect of financial management are increasingly decentralized to regional autonomy.

Azwardi (2007) in research on the Impact of Fiscal Decentralization Toward Economic Performance Inter-Regional in Indonesia were analyzed using a general equilibrium model, or interregional Computable General Equilibrium (IRGE) find that fiscal decentralization in Indonesia have an impact on the increase in economic performance between regions in Indonesia but on the other hand there is a trade-off between economic growth and the level of income inequality where economic growth will be accompanied by increased income inequality in both the micro region.

By paying attention to the conditions that existed then transfer to local funding provided in accordance with the existing capabilities in the area. The magnitude of fiscal funds are transferred every region is not the same so that the resulting potential differences in levels of development of the region. See the percentage of transfer of funds allocation given to the local area has to spend the funds in accordance with the principles of state financial management accountable and transparent. The area has an obligation to utilize other sources of income to spur economic development. According to research conducted by Susiyati (2007) most of the region is willing to increase the role of local revenue, but due to lack of understanding of the principles of good tax the many efforts made the area even interfere (distorting) the activities of economy area. Levies, which made the area even interfere with the investment and business climate in the area. The tax levies have led to high production costs that should not have happened.

As presented in the previous section that the actual implementation of fiscal decentralization policy in the region aimed at improving the welfare of the region. Regional better understand what the needs and interests of the necessary in order to accelerate the process of improving the welfare of society, which in turn can be seen the extent to which the success of a development undertaken. The success of a development that do certainly need to have the right size. In this case the United Nations Development Programme (UNDP) as the biggest international organization in providing technical assistance and development in the world has developed a wide range of measures of development success. One that is often a point of calculation is the Human Development Index (HDI) and the achievement of development goals of the Millennium Development Goals (MDGs) and sustainable development goals (SDGs).

In 2000 there were 189 member states of the United Nations (UN) has agreed to eight Millennium Development Goals as a commitment to abolish poverty and achieving other human development goals by 2015 (Todaro and Smith, 2011). IPM and the achievement of the Millennium Development Goals (MDGs) in 2015 has become Indonesia's commitment to development in all fields. Human development index is a proxy for the performance of human-centered development (people centered development), while the MDGs are human development targets by 2015. UNDP MDG outlines into specific targets by 2015, namely: (1) reduce by half the number of people living with income less than $\$ 2$ per day, halve the number of hungry people (2) ensure that all boys and girls to complete primary education, (3) remove gender disparities in primary and secondary education in 2005 and at all levels by 2015 , (4) reduce by two thirds the mortality rate of children under 5 years of age, (5) reducing the risk of maternal mortality by three-quarters in the period up to $2015,(6)$ to halt and begin reducing the spread of HIV AIDS, stop and begin to reduce the number of people affected by malaria and other major diseases (7) to integrate the principles of sustainable development into policies and programs of the state, reduce the damage to natural resources, reducing by half the number of people who do not have access to clean drinking water (8) further developing trade and financial system more open, to handle the special needs of developing countries and small island states (Todaro and Smith, 2011). Especially for the development of the South Sumatra provincial HDI Regency / City in 2010-2013 can be seen in Table 1 below: 
Table 1 - The development of IPM Regency / City in South Sumatra province, 2010-2013

\begin{tabular}{clllll}
\hline No & Kabupaten/Kota & 2010 & 2011 & 2012 & 2013 \\
\hline 1 & Ogan Komering Ulu & 73.14 & 73,59 & 74.01 & 74.42 \\
2 & Ogan Komering llir & 70.61 & 71,07 & 71.45 & 71.82 \\
3 & Muara Enim & 70.81 & 71,26 & 71.65 & 72.06 \\
4 & Lahat & 71.30 & 71,83 & 72.29 & 72.68 \\
5 & Musi Rawas & 67.89 & 68.38 & 69.01 & 69.57 \\
6 & Musi Banyuasin & 71.81 & 72.44 & 73.15 & 73.67 \\
7 & Banyuasin & 69.78 & 70.28 & 70.70 & 71.08 \\
8 & OKU Selatan & 71.42 & 71.82 & 72.29 & 72.67 \\
9 & OKU Timur & 69.68 & 70.34 & 70.72 & 71.19 \\
10 & Ogan Ilir & 69.51 & 70.09 & 70.52 & 70.89 \\
11 & Empat Lawang & 68.61 & 69.08 & 69.69 & 70.02 \\
12 & Palembang & 76.23 & 76.69 & 77.38 & 77.74 \\
13 & Prabumulih & 74.27 & 74.94 & 75.45 & 75.83 \\
14 & Pagar Alam & 73.19 & 73.70 & 74.15 & 74.47 \\
15 & Lubuk Linggau & 70.56 & 71.10 & 71.46 & 71.83 \\
\hline
\end{tabular}

Source: South Sumatra in Figures, 2014.

The table above shows the level of development of IPM, spread in 15 districts / cities in the province of South Sumatra. The data show that each District / City have varying levels of development HDI but still many regencies / cities that have HDI that is below the average of South Sumatra province. In 2010 the average HDI in the province amounted to 72.95. In the year 2010 there are 11 districts that have HDI under the provincial average and 4 Regency / City that have $\mathrm{HDI}$ above the provincial average. In 2011 the average $\mathrm{HDI}$ in the province is 73.42. There are 11 districts that have HDI below the provincial average and 4 Regency / City that have HDI above the provincial average. In 2012 the average HDI in the province is 73.99. There are 11 districts that have HDI below the provincial average and 4 Regency / City that have HDI above the provincial average. In 2013 the average HDI province is 74.36. There are 11 districts that have HDI below the provincial average and 4 Regency / City that have HDI above the average of South Sumatra province.

Indonesia's commitment is already very strong in the human-centered development. One of them is the use of indicators of human development index to measure the magnitude of the base budget of central transfers to the regions through the general allocation fund (DAU). This is good policy, in terms of budget revenues, should be followed by a solid foundation of the shopping areas, namely by showing what the most appropriate sector as a basis for fiscal decentralization to accelerate regional development. In other words, at least no scientific basis and why the education sector or the health sector should be prioritized human development in Indonesia over the years.

The fact that happened indicates that fiscal decentralization under the authority of the Government, the Provincial Government particularly regency / municipal government, which is associated with efforts to increase the nominal rate Human Development Index has not been done with the application of the concept of impartial, it occurred because of the formation of an economic model which analyzes the impact of spending the fiscal decentralization policy that does not explain the combination of the amount and period of time in achieving human development targets. So far, fiscal decentralization by the Government or the Provincial / District / City most is to increase the budget of the education sector or the health sector. Enlarge options education sector budget by the Constitution of 1945 , and amendments thereto, which mandates a minimum allocation of 20 percent of the total budget. While the choice of enlarging the health sector based on the priorities that all processes of development requires a healthy human being so that it can work well, besides that consideration that the health sector containing component life expectancy which is forming a common identity Human Development Index.

IPM in Special Province capital, the Province of Aceh, South Sumatra Province, Papua Province, the Province of West Sumatra, Lampung, East Java, Bali Province, West Kalimantan and North Sulawesi can be used as an example of disparity achievements of the human development index between regions in Indonesia. Further that the disparity in the 
human development index implies also the disparity in part to the whole of variables forming human development indices, such as life expectancy, literacy rates, average length of school, and earnings per kapita approached with purchasing power. Disparities in human development index among the provinces is certainly formed because of the disparity in the human development index that exist in each district / city in each province. Based on the report of the United Nations Development Programme (UNDP) in 2013 that the Human Development Index for Indonesia was ranked 121 out of 187 countries. When compared with neighboring countries a fellow member of the Association of Southeast Asian Nations (ASEAN), the rating index of human development in Indonesia is still far behind, especially from Singapore who is ranked 18, Brunei Darussalam ranked 30th, Malaysia is ranked 64, Thailand ranked 103, ranked the Philippines 114 . The Indonesian government apparently still has not found the right formula to achieve it. Therefore, the nominal value of Indonesia's human development index is still lagging behind the MDGs and SDGs. Logically the nominal index of human development in Indonesia will increase if the index of human development throughout the Province / Regency / City in Indonesia increased, the nominal rate of human development index would increase if the rising indices of its components, namely: the index for decent living are the main element is the expenditure per capita based on purchasing power, long-life index element is life expectancy, and the Education Index which element is the literacy rate and average Old School. Meanwhile, efforts to improve the three indexes are economically can be done by increasing investment in provincial or district / city concerned, either in the form of investment capital resources and investment in human resources. Based on the previous description that the problem in this research are: 1. How does the shopping areas to the improvement of education index? 2. How does the shopping areas to the improvement of health index index? And 3. How does the shopping areas to the improvement of the Human Development Index?

\section{THEORETICAL BASIS}

Theories have Fiscal Policy. Fiscal policy is the policy pursued by the government with regard to setting government spending and tax revenue through the set. Fiscal policy is conducted by the government when the economy goes way above or below the level of Gross National Product (GNP) potential (Samuelson and Nordhaus, 1989). Fiscal policy will affect the total amount of consumption instead of individual consumption. Fiscal policies that apply to setting government spending intended to regulate the level of production and consumption. While fiscal policy in the field of taxation intended to reduce revenue at a certain level so that in the end will reduce private consumption, however, the tax would affect investment and potential output.

Demand and Aggregate Supply. Fiscal policy affects the economy (income and interest rates) through aggregate demand in the market for goods, while monetary policy influences economy (income and interest rates) through the Central Bank intervention on the money market and bond market (securities). Therefore, fiscal policy and monetary policy is often used as an instrument to stimulate and stabilize the economic upheavals that undermine economic growth (Dombusch, 2004).

The Effects of Fiscal Policy Aggregate Demand. Regarding to the relationship IS-LM curve and the $A D$ curve at the top, then intervention in the goods market is called fiscal policy and money market intervention, the so-called monetary policy affects the economy. Fiscal policy affects the economy through increased government spending and tax rates. The magnitude of the effect of fiscal policy on the economy (income and interest rates) through changes in the IS curve can be calculated from the following equation (Dombusch, 2004):

$$
Y=\alpha G(\tilde{A}-b i) ; \alpha G=1 /\{(1-c(1-t)\}
$$

Where: $Y=$ Income; $\alpha G=$ Coefficient or variable parameters; $\tilde{A}=$ Exogenous variables; $b=$ Coefficient; $c=$ Marginal propencity to consume; $t=$ Tax. 
Effects of Fiscal Policy on Aggregate. Gross Domestic Product (GDP) on the supply side is the sum of all the value of production (output) sectors of the economy. Fiscal policy through increased government expenditure will increase revenue / output and increase employment (L), and reduce unemployment $(\mathrm{U})$, which is the difference between the level of achievement at the end of the balance point is reduced achievement in equilibrium prior to fiscal policy. Final achievement is generating new levels of income $\left(Y^{*}\right)$, the level of new interest rate $\left(r^{*}\right)$, new price level $\left(P^{*}\right)$, the level of the new wage $\left(W^{*}\right)$ and the employment rate of new $\left(L^{*}\right)$, and the unemployment rate The new $\left(U^{*}\right)$.

\section{NEEDS AND FISCAL CAPACITY}

Needs Fiscal and Estimates. Each region (subnation) should provide minimum public services (vital) to the people who are in its territory, regardless of whether they are permanent residents or immigrants. Many areas that bear much of the burden of fiscal responsibility, for example, an area that has a lot of poor people, or the region with the proportion of school-age population (6-18 years) high, areas with a vast territory and population spread should bear the burden of expenditure per capita is very high for road construction and maintenance. This all reflects the magnitude of the fiscal needs for cost in the provision of public services is high or the scope of the programs that must be implemented by the regions widened.

Basically, fiscal needs the need to fund all expenditure in order to carry out the functions and authority of the region in providing public services (expenditure needs). World Bank (2009) states that the fiscal needs which must be met determine a country to finance the fiscal deficit larger without jeopardizing macroeconomic stability and debt sustainability. Needs owned by the county basically reflects the scale of service requirements (size of service provision), the cost of the provision of services (cost of service provision) and the requirements of development (development need).

To calculate or measure the true fiscal needs of an area is not easy. In the first approach, the first step taken is to divide spending / shopping areas over several categories. The common ones usually are: education, health, transportation, telecommunications, social welfare, police and fire, environmental maintenance, and other services. The division is of course likely to vary between countries depending on the powers / functions held by the regions. But put forward above is typically functions in the hands of the area.

This category also depends on the budgetary provisions in each country and the availability of data. For example, transportation and telecommunications may be in combination, police and fire departments are separated (or police abolished because in Indonesia is not a local government authority), education is divided into primary, secondary, and higher, and so on.

If the measurement of fiscal needs this in order to make the transfer of funds equalization formula, which takes into account the needs of many countries with a regular expenses also include costs of maintenance projects. The cost of new projects are usually issued for other than the numbers tend to be large, it is also difficult to find indicators needs. Besides the benefits tend to be long term, so it would be contrary to "benefit principle " of the tax if the cost of the project is entirely financed from current tax sources. The second step is to calculate the need (costs) expenditures from each category, and add everything to gain local fiscal needs. Illustration for the following categories may clarify the above description. Raw formula used to calculate the expenditure category $\mathrm{i}$ based on this approach by Simanjuntak (2003) are:

$$
\mathrm{Ni}=\text { measurement units * the average cost per unit * index adjustment }
$$

Where: i shows the type or category of expense to $-i$, such as education, health, transportation and so forth. Measurement unit is the number of units that received local government services. The average cost per unit is the amount of regional spending for the 
category i divided by Measurement unit adjustment index is a combination of factors that makes the difference of the cost per unit of service in the area of the national average.

Basic and Secondary Education:

Measurement unit $=$ the number of population aged 6-18 years.

$$
\text { Adjustment index } \mathrm{WI}=\mathrm{a} 1+\mathrm{a} 2+\mathrm{a} 3 \mathrm{RCI} \mathrm{SDI}+\mathrm{a} 4 \mathrm{PFI}
$$

WI or index salary (wage index) is the ratio (ratio) between salaries in the region against the national average. $\mathrm{RCl}$ or lease cost index (rental cost index) is the ratio of rental costs per unit area in an area specific to average nasioanal. SDI or disabled family index (student disability index) is the ratio of the percentage of students with disabilities in the area of the national average. PFI or index poor families (poor family index) is the ratio of the percentage of students from low-income families in the region against the national average.

The four factors above are given great weight of the whole is equal to one (so, a1 $+a 2$ $+a 3+a 4=1$ ). Weights can be determined the same or different, and can be searched through various means / methods such as econometrics.

Health:

Measurement unit $=$ the number of residents of the area concerned.

The average cost per unit $=$ per capita health expenditure of the state.

$$
\mathrm{HPI} \text { adjustment index }=\mathrm{a} 1+\mathrm{a} 2+\mathrm{IMI}+\mathrm{a} 3 \mathrm{a} 4 \text { ILEI IPDI }
$$

HPI or health cost index (health price index) is the ratio of the cost of health care in the region against the national average. IMI or indices of infant mortality (infant mortality index) is the ratio of infant mortality rate in the region against the national average. ILEI or life expectancy index inverse (inverse expectancy index) is the ratio of the average rate of the national life expectancy to figure the area. IPDI or inverse population density index (inverse population density index) is the ratio of the average number density of the national population to population density regions concerned. $a 1+a 2+a 3+a 4=1$.

Transportation:

Measurement unit $=$ total length of roads in the area.

The average cost per unit = expenditure per capita for transportation from the state.

$$
\text { Adjustment index } \mathrm{WI}=\mathrm{a} 1+\mathrm{a} 2+\mathrm{a} 3 \mathrm{GRI} \mathrm{SNI}+\mathrm{a} 4 \mathrm{IPDI}
$$

WI or index salary (wage index) is the ratio of local salary levels to the national average. GRI or index path (road grade index) is the ratio of the average quality of roads in the area to the national average. SNI or indexes snow (snow index) is the ratio of annual snowfall in the region against the national average. IPDI is the inverse population density index (inverse population density index) is the ratio of the average national population density to the density of the area. $(A 1+a 2+a 3+a 4=1)$.

The results of the three categories above calculations later summed with the results of other categories to obtain all the fiscal needs of the region concerned. However, of the three examples above show that the required data is complete and accurate so that a good overview of the needs of each category can be estimated. This is the main difficulty in applying the method. Some countries are using this method is the United Kingdom, Australia, Japan and South Korea.

Given the difficulty will be the data as described above, then the alternative method is to use fewer variables to estimate the fiscal needs of a region. Formula used can vary widely. Here are some examples:

Estimating the fiscal needs of a region based on population, area, and income level of the area:

$$
\mathrm{Ni}=\mathrm{TE}(\mathrm{WP}(\mathrm{Pi} / \mathrm{SjPj})+\mathrm{Wi}(\mathrm{IDiPi})+(\mathrm{WA}(\mathrm{Ai} / \mathrm{SAl})
$$


Where: $\mathrm{Ni}=$ the fiscal needs of the region I; TE $=$ the total expenditure areas concerned; $\mathrm{Pi}=$ the population of region I; $\mathrm{Wp}=$ the weight for the population; IDI = the distance, per capita income in the richest area; $\mathrm{Wi}=$ the weight for the income disparity; $\mathrm{Ai}=$ the area that concerned; $\mathrm{Wa}=$ the weight to area $\mathrm{WP}+\mathrm{wi}+\mathrm{wa}=1$.

The total area included in the formula because of these variables play a role in determining the cost of providing public services. The provision of roads, telecommunications, schools and libraries, for example, will demand a higher fee vast area with sparse population compared to areas densely populated. The inclusion of distance with a per capita income of the richest regions is a reflection of the desire to deal with imbalances between regions (Simanjuntak, 2003).

Estimating the fiscal needs of the area by using indicators of health and education:

$$
\text { Hii ni }=\text { SII } x \times \text { Pi xc }
$$

Where: $\mathrm{Ni}=$ the need of the region's fiscal I; SII = an index of students (student index); $\mathrm{SII}=(\mathrm{S} / \mathrm{P}) /(\mathrm{Si} / \mathrm{Pi}) ;$ hii $=\mathrm{a}$ health index $($ health index $) ;$ hii $=(\mathrm{H} / \mathrm{P}) /(\mathrm{Hi} / \mathrm{Pi})$; $\mathrm{Pi}=$ the population of region $\mathrm{I} ; \mathrm{C}=$ the per capita expenditure on the country concerned; $\mathrm{Si}=$ the number of students in the region $\mathrm{I} ; \mathrm{Hi}=$ the number of health workers in the area $\mathrm{I} ; \mathrm{P}$ $=$ the number of people in the countries concerned; $S=$ the number of students in the country concerned; $\mathrm{H}=$ the number of health workers in the country concerned.

SII in outline measures the reception level (capacity) of the region i relative to national capacity. Hii measure of health workers per capita in region i relative to the national average.

Estimating the fiscal needs with the welfare indicators:

$$
\mathrm{Ni}=\mathrm{EII} \times \mathrm{TI} \times \mathrm{Pi} x \mathrm{C}
$$

Where: $\mathrm{Ni}=$ the need of the region's fiscal I; EII = an index of power (electricity index); $\mathrm{EII}=(\mathrm{E} / \mathrm{P}) /(\mathrm{Ei} / \mathrm{Pi}) ; \mathrm{TII}=$ the index of telecommunications (telecommunication index); $\mathrm{TII}=(\mathrm{T} / \mathrm{P}) /(\mathrm{Ti} / \mathrm{Pi}) ; \mathrm{Pi}=$ the regional population $\mathrm{I} ; \mathrm{C}=$ the expenditure per capita of the country concerned and where $\mathrm{Ei}$ is the level of consumption / electricity usage area I; $\mathrm{Ti}=$ the number of telephone connections in the region $\mathrm{I} ; \mathrm{P}=$ the national population; $\mathrm{E}=$ the total national electricity consumption; $\mathrm{T}=$ the total national telephone connection.

$\mathrm{Ei}$ and $\mathrm{Ti}$ measure electricity consumption and telecommunications relative to the national average.

Fiscal capacity and Estimates. As with fiscal needs, there are many ways to measure fiscal capacity. In most developed countries, an estimated capacity using main tax base and rate of the standard tax rate (on average). This method measures the fiscal capacity of a region of the reception area that can be assembled if the taxing all standard tax base with tax effort (tax effort) are standard anyway (Simanjuntak, 2003).

The general form of the formula is:

$$
\mathrm{Ci}=\mathrm{SjBij} \times \mathrm{tj}
$$

$\mathrm{C} i$ is the tax capacity (tax capacity) region $\mathrm{I}, \mathrm{Bij}$ is the tax base to the region $\mathrm{I}-\mathrm{j}$, and $\mathrm{tj}$ is the standard (eg effective national average) level of tax rates to the tax base-j. it is important to wear a standard tax rate (national) than the effective tax rate of the relevant area, to avoid "punishment" of areas that have a tax effort (tax effort) and stimulate high (encourage) local tax effort is low. In other words, if the effective tax rate of a region is higher than the national average, transfers received are not becoming less; and when the effective tax rate is lower than the area average of national, transfer derives not be increased.

This method requires some implementation steps. First, determine the tax base. Second, collect data from the taxes selected. Here can be used year figures seblumnya. Third, determine the tax rate (tax rates) are standard. Fourth, calculate fiscal capacity based on the equations / formulas above. Method of measuring fiscal capacity above takes the data is complete, accurate, and detailed, which is obviously very difficult to meet, especially in 
developing countries (Simanjuntak, 2003). Therefore, fiscal capacity is often measured using a number of variables or other indicators, such as: a. Gross Regional Domestic Product (GRDP), b. Individual income (the sum of all income locals), and c. Total Retail Sales in Region.

The gap Fiscal (Fiscal Gap). The fiscal gap (fiscal gap) is the difference between the fiscal needs required by a region in implementing basic services to their communities with a fiscal capacity or ability possessed by the region in meeting those needs. The fiscal gap that occurs in an area due to the inequality between the needs of fiscal capacity. In an area that has a high degree of fiscal gap, the allocation of funds transfer regions through the DAU will be of great value to close the fiscal gap. By contrast, in areas with high fiscal capacity then transfer DAU funds will be smaller portions.

An area with high fiscal capacity indicates that the area has to have a better ability to manage existing resources, local financial independence is also better than in other regions. Many studies show that the potential for inequality among regions, with the implementation of decentralization is quite large. Potential tax uneven areas and distribution of natural resources are also uneven requires significantly to reduce the horizontal inequality. Since the enactment of the Law on financial balance between central and local government then introduced new sources of revenue, namely general allocation fund (DAU). The purpose of giving DAU is to ensure equity across regions. DAU actually used to close the fiscal gap (Fiscal Gap) which represents the difference between needs and fiscal capacity.

General Allocation Fund (DAU). The general allocation fund (DAU) is one and transfer the funds sourced from the State Budget (APBN) and used for the purpose of equalization of fiscal capacity in the implementation of decentralization. DAU is a grand block which means the user submitted to the local government in accordance with the priorities and needs of the regions to improve services to the public. DAU is allocated to the provincial government and the district government / municipality in accordance with the balance of powers between provincial and district / city.

DAU formula using the fiscal gap approach (fiscal gap) which is the difference between the fiscal needs and fiscal capacity and allocation base form of salaries of civil servants in each region (Leaflet Ministry of Finance of the Republic of Indonesia). DAU is calculated by the following formula:

$$
\mathrm{DAU}=\text { Basic Allocation }(\mathrm{AD})+\text { Fiscal Gap }(\mathrm{CF})
$$

Where: the basic allocation $=$ Salaries regional civil servants; the Fiscal Gap $=$ Needs

Fiscal - Fiscal Capacity. The magnitude of the allocation of basic salaries of civil servants salaries of civil servants are calculated based on the realization of the region the previous year ( $\mathrm{t}-1)$, which consists of a basic salary and allowances attached to the salary component in accordance with the regulations governing all departments / agencies. The formula used to calculate the fiscal needs are:

$$
\mathrm{KBF}=\mathrm{TBR}(\alpha 1 \mathrm{IP}+\alpha 2 \mathrm{ILW} \alpha 4 \mathrm{IKK}+++\alpha 3 \mathrm{IPM} \alpha 5 \mathrm{IPDRB} / \mathrm{hood})
$$

Where: $\mathrm{KBF}=$ Needs Fiscal; TBR $=$ Total average spending budget; IP $=$ index number of population; area ILW = Index; $\mathrm{HDI}=$ human development index; $\mathrm{CCl}=$ construction cost index; IPDRB = the GDP index; $\alpha=$ Weight index.

Fiscal capacity obtained from local revenue (PAD), and revenue sharing $(\mathrm{DBH})$ with the following formula:

$$
\mathrm{KPF}=\mathrm{PAD}+\text { Taxes }+\mathrm{DBH} \mathrm{DBH} \text { SDA }
$$

Where: KPF = fiscal capacity; Revenue = revenue; $\mathrm{DBH}=$ Revenue-sharing.

Formulation DAU for each region has gone through various stages to the establishment of the DAU. Stages include (1) Academic Stages, (2) Stages Administrative, (3) Technical Stages, (4) Politics Stages. 
Special Allocation Fund (DAK). Special allocation fund is one source of revenue for the regions that come from central government. DAK is a complement of DAU transfered to local governments. Activities that can not be tackled with commitment and DAU and be included in the national priorities funded through DAK. In Act No. 33 of 2004 Article 1 Point 23 states that the Special

Allocation Fund is a fund sourced from APBN allocated to certain regions with the aim to help fund special activities of regional affairs and in accordance with national priorities. Special activities funded by DAK is a necessity that can not be predicted in general by using the DAU formula. Further regulation of DAK is regulated by Government Regulation No. 55 of 2005 on the balance funds. Implementation of DAK activities are focused on the development investment, procurement, or repair of physical infrastructure of public services with the economic life long including the provision of means of physical support but does not include equity investments, fund administration activities, preparation of physical activities, research, training and official trips, As a commitment shared between the central government and local governments, the regions receiving it must allocate matching funds sourced from budget funds at least $10 \%$ of the total DAK receives. DAK set by the relevant Minister after coordination with the Minister of the Interior, the Minister of Finance and Minister of State for National Development Planning.

After a set of programs and activities being targeted DAK, then the next process is the determination of a particular area as a receiver and determining the amount of DAK allocation for each region. Determination of the area as receiving it must meet one of three criteria: (1) general criteria (2) specific criteria (3) technical criteria. The general criteria formulated by the financial capacity of the area is reflected in the general acceptance of the budget after deducting expenditure PNSD (Audit Board RI). The formula is:

$$
\begin{aligned}
& K K D=P U A P B D-\text { Regional BP } \\
& P U=P A D+D A U+(D B H-D B H D R) \\
& B P=\text { Shopping PNSD }
\end{aligned}
$$

Where: $\mathrm{KKD}=$ Financial fitness area; Public Works budget $=$ Revenue ABPD; $\mathrm{BP}$ Regional $=$ Personnel expenditure areas; $\mathrm{PU}=$ Revenue general; $\mathrm{PAD}=$ Revenue; the DAU = Dana general allocation; $\mathrm{DBH}=$ Revenue-sharing; DBHDR $=$ Revenue-sharing funds reforestation; $\mathrm{BP}=$ Shopping clerks, civil servants $\mathrm{PNSD}=$ area.

An area in the category of special autonomy in Papua such an area eligible for DAK. If it does not meet the characteristics of the visible region using territorial characteristics Index (IKW). Combined Net Fiscal Index (IFN) and Regional Characteristics Index (IKW) produces Fiscal and Regional Index (IFW). If the sum of IFN with IKW value is greater than 1 then the area automatically eligible for DAK allocation.

Determination of areas based on technical criteria is based on indicators that can describe the condition of the facilities and infrastructure and the employment rate of service to the community and technical achievements implementation of DAK activities in the area. The technical criteria established by the relevant technical minister. From the above it can be concluded that an area eligible for DAK if it meets the following criteria: (1) the area that has the financial capacity of the region below the national average (2) area that includes special autonomy in Papua and the area with category lagging behind regions other (3) areas that have tilapia fiscal index larger region than the number 1 (one). The process further includes determining the allocation of DAK in each region. DAK allocation determination based on the weighted area (BD), technical index (IT) and technical weight (BT). Obtained by multiplying the weight of the IFW with IKK. The technical index (IT) is determined by each field. Technical weights (BT) is obtained by multiplying IT with IKK. Allocations are set for the next areas are categorized according to their respective fields in accordance with the technical aspects of these programs and activities. Table 2 below shows the number of the DAK target and objectives of the activities: 
Table 2 - Total Field DAK

\begin{tabular}{cll}
\hline No & & Bidang DAK \\
\hline 1 & Education & \\
2 & Health & \\
3 & Roads Infrastructure & \\
4 & Irrigation Infrastructure & \\
5 & Infrastructure Water and Sanitation & \\
6 & Government Infrastructures \\
7 & Kalautan and Fisheries \\
8 & Agriculture \\
9 & 9 Environment \\
10 & Family Planning \\
11 & Forestry \\
12 & Rural Infrastructures \\
13 & Trade
\end{tabular}

Source: Ministry of Finance of the Republic of Indonesia.

$D B H(D B H)$. The central government gives the policy of profit sharing with the provincial government and district / city government as part of the exploitation of natural resources by the central government. The amount of funds for a given outcome variable proportions between the central, provincial and district / city. Provision of funds for these results depends on the potential areas with the status of a producer or not. Revenue-sharing is comprised of (1) tax sharing (2) funds for natural resource revenue. The allocation of funds for the results implemented based on the principle by origin (region). Tax sharing are further defined by the relevant minister to pay attention to the circumstances that developed along with the ongoing development process. In the tax sharing is also included the percentage to be gained by each region according to their capacities. Funds for the results that come from natural resources consist of the kind of reception as follows: (1) receipt of forestry (2) general mining revenues (3) receipt of fisheries (4) acceptance of oil and gas mining (5) acceptance of geothermal mining.

Revenue from forestry sourced from Forest Tenure Contribution (HPH), Forest Resource Provision (PSDH) and Reforestation. Revenue from general mining sourced from Fixed Levy (Land Rent) and Contribution Exploitation (Royalties). Revenue from fisheries sourced from Exploitation Charges Levied Fisheries and Fishery Products. Funds for the results of the fisheries sector is divided equally large portion of those districts / cities throughout Indonesia. Revenue from the petroleum mining sourced from petroleum products are exploited in the area after tax and other levies in accordance with the provisions. Revenue from the exploitation of natural gas derived from natural gas net of taxes and other levies according to regulations. The draw of revenue from oil and natural gas are the specific allocation for basic education with a value of $0.5 \%$. Revenue from geothermal mining deposits sourced from the government's part, permanent contributions and production. For the results of these funds tailored to each region status as producer or not as a producer.

Table 3 - Percentage of DBH Natural Resources

\begin{tabular}{llccccc}
\hline \multirow{2}{*}{ No } & \multicolumn{1}{c}{ Acceptance } & \multicolumn{5}{c}{ Percentage } \\
\cline { 3 - 7 } & & Center & Prov & District / City & District / City More Autonomy & Otsus \\
\hline 1 & Forestry & 20 & 16 & 64 & - & 80 \\
& a. IHPH & 20 & 16 & 32 & - & 80 \\
& b. PSDH & 60 & - & 40 & - & 40 \\
& C. Reforestation Fund & & & & 32 & 80 \\
2 & General Mining & 20 & 16 & 64 & 80 & 80 \\
& a. Land rent & 20 & 16 & 32 & 6,2 & 80 \\
& b. Royalties & 20 & - & - & 12,2 & 70 \\
3 & Fishing & 84,5 & 3,1 & 6,2 & 32 & 70 \\
4 & Petroleum & 69,5 & 6,1 & 12,2 & 32 & 80 \\
5 & Gas & 20 & 16 & 32 & & \\
6 & Geothermal & &
\end{tabular}

Source: Ministry of Finance of the Republic of Indonesia DJPK 2014. 
Human Development Index (HDI). The initial concept the United Nations Development Programme (UNDP) defines human development as a process of expanding the choice for people in his life. In the concept of the human being is placed as the final destination while the implementation process of development is a means to achieve the ultimate goal. To achieve the ultimate goal of human development that is both helpful and there are four main things that need attention: (1) productivity (2) equity (3) sustainability (4) empowerment. In each building, the productivity of society must be enhanced in order to meet the needs of the community. A process of development must be able to give way and increase the productivity element of society. Productivity give a good impact on the outcome of development but with the concept of equalization is run in accordance with the principle of development for all. Communities should have the opportunity, and equal opportunities to gain access to all the resources of economic and social development and enjoy the fruits of development are equitably. Obstacles that arise and can minimize opportunity to obtain access should be minimized.

Utilization of natural resources within the framework of the development process that is equitable and productive done while maintaining the availability of natural resources in the future. Natural resources are not to be spent in a time course but maintained its continuity to the production process in the future. In maintaining the continuity of the then all communities should participate fully in the development process.

To generate a development process that takes into account the elements mentioned above, it is developing an optimal size to represent the purpose of the concept of development is expected. That concept is the Human Development Index (HDI). IPM was initiated to address dissatisfaction with the experts in assessing the performance of development based solely on macroeconomic indicators alone. Originator originally was Mahbub UI Haq, a Pakistani economy which in 1970 expressed dissatisfaction with the performance measures of socio-economic based solely on indicators of average national income per capita and its derivatives such as inflation, unemployment, the level of investment, the level of government spending, the level of consumption, and the balance of payments (Anand, 2000).

Mahbub UI Haq idea that the core of the existing human-centered development paradigm (people centered development) that puts human beings as well as connoisseurs of development actors. Therefore, macroeconomic indicators as a performance measure of economic growth is not the final achievement of human development but only as an intermediate targets that must be passed in order to achieve the ultimate objective of human development is human welfare.

Centered on human development has been promoted consistently in the Development Programme of the United Nations or UNDP since 1990. Since then UNDP released its annual report of human development growth for the countries in the world based on different themes but still about human interests (UNDP, 1990-2009). Along with that UNDP continues to promote Human Development Index (HDI) or index development humans as the main tool for measuring human development in addition to indicators of derivatives such as Gender

Development Index (GDI), Index Gender Empowerment (IDG) and the Human Poverty Index (HPI) and more applicable then as well as macroeconomic indicators that already exist as complementary indicators. Still the use of macroeconomic indicators as complementary indicators of human development is understandable because the macroeconomic indicators described the achievement as the process of economic growth performance among towards human development. Another reason the use of macroeconomic indicators for measuring the performance of the Development humans are (1) the economic aspects appear on the surface more quickly between various aspects of human life. (2) the economic impact more easily quantified than social impact is essentially qualitative. (3) Assessment of the economic aspects of development performance has been more than aspects - other aspects of the social sciences and (4) The macroeconomic indicators such as revenue has been studied as an endogenous variable of an economic model that can be foreseen magnitute and term accomplishments. Human development index as a measure of human development performance is not too perfect. Because it does not measure all indicators of human 
development due to not fully quantified. Other weaknesses of the human development index and its components for formation (life expectancy / $\mathrm{AHH}$, adult literacy rate / $\mathrm{AMH}$, Average Length of school / RIS and per capita income) is not used as an endogenous variable of a simultaneous equation, so it is unknown economic relations between variables and can not be simulated how factually achievements yet least recognized human development indices and widely adopted by UN member states, including Indonesia.

According to UNDP (2009) that the achievement of human development indices Indonesia and 186 other countries have a tendency that increased from 1980 to 2007 . This suggests that economic growth and human development performance improvements simultaneously around the world. The higher human civilization marked by increasing technology in all fields. Humans increasingly creative, innovative and productive. The tendency of Indonesian human development index from 1980 to 2007 increased as measured by a scale of 0 to 1 . If it is in the percentage and then the highest value is $100 \%$.

$\mathrm{HDI}$ increased as a result of the increase in the value of the combination of its constituent indicators, namely life expectancy, literacy rates, average length of school and purchasing power. While life expectancy increased performance due to improvements in the health indicators, such as the decrease malnutrition, decrease in infant mortality, and a decrease in maternal mortality. In other words, it is certain indicators - indicators above is linked to one another and become factors - factors that affect the formation of the human development index. For the purposes of this study, the main concern is shown on the indicator - an indicator of human development indices forming the objectives of the MDGs, then analyzed its association with Indonesia's macro economic indicators.

$\mathrm{HDI}$ value of a state / province / county / city shows how far the region has reached a predetermined target both in the field of education, health and per capita spending. The greater the value of the HDI the closer they approach the region of the basic goals of the development process is expected. HDI which only includes three basic components of education, health and spending per capita, the three values should be seen as a simplification of the complex reality of the extent dimension human development. In certain cases $\mathrm{HDI}$ value is very sensitive to measure something that happens in economic activity, especially on components increased purchasing power. In case of a financial crisis, as happened in the Republic of Indonesia, the crisis has led to a change in the form of reduced purchasing power in many communities. Changes in the purchasing power of these are things that can be observed directly on the economic life of society. As a result of the decline in purchasing power also affected the basic human needs both education and health sectors.

Factors Shaping the Human Development Index. Components HDI is composed of three components, namely the length of life measured by life expectancy at birth, educational level is measured by a combination of literacy rate in the adult population (with a weight of two-thirds) and the average length of the school (with a weight of one third), and the level of a decent living as measured by per capita expenditure has been adjusted (PPP rupiah), this index is a simple average of the three components mentioned above:

$$
\mathrm{HDI}=(\mathrm{X} 1+\text { Index Index Index X2 + X3) }
$$

Where: $\mathrm{X} 1$ = Life expectancy; X2 = Education; X3 = Standard decent life $/$ health.

$$
\text { Index X }(I, J)=(X(I, J)-X(i-m i n)) /(X(I, J)-X(i-m a x))
$$

Where: $X(I, J)=$ Indicators to-I from the $\mathrm{J} ; \mathrm{X}$ (i-min) $=$ minimum value of $\mathrm{Xi}$; $\mathrm{X}(\mathrm{i}-\mathrm{max})=$ maximum value of $\mathrm{Xi}$.

Relationship Between Fiscal Decentralization Policy by the Human Development Index. Fiscal decentralization policy which is implemented by providing transfer funds to each regency / municipality in accordance with its portion henceforth be revenue for the region is a consequence that is executed in connection with the application of the concept of fiscal decentralization policy. It could be a revenue income through the General Allocation Fund, 
Special Allocation Fund, DBH or other legitimate income formulated exactly in accordance with the instructions issued by the Ministry concerned to be shopping at the Regional Budget.

Transfer of funds included in existing programs and activities at the regional work units through the budget and work plan in the list of budget implementation for the year. The funds are used in accordance portion. For example, the transfer of funds from the Special Allocation Fund for Education then the usage must correspond to the field of education. Special Allocation Fund for Health then the user must also comply with the health sector, as well as with other funds transfer.

If indeed the transferred funds are used according to its purpose then of these expenditures will affect the development and progress of each field. In education, the use of funds according to the program and activities will be able to add to the educational facilities both in primary education and in secondary education, including expanded access to the completion of illiteracy (literacy). In the medical field the use of transfer funds will be able to add a variety of health facilities at the lowest level (HEALTH), additional health personnel and various medications needed by society and development activities carried out against society. Infrastructure construction other than education and health also spur the economic development of society. This economic development will ultimately improve people's lives through income and other access devices received as a result of the economic development in the region. Component areas of education, health and access to economic improvement mentioned above which have increased as a result of the shopping process through funds from the central government transfers to local government will eventually improve the Human Development Index which is made up of various components which have been set at the previous section.

The hypothesis in this study are:

1. Shopping areas education sector, gross regional domestic product and the general allocation funds affect the education index.

2. Shop local health sector, regional gross domestic product and special allocation funds affect the health index.

3. The total shopping area, the regional gross domestic product affect the human development index.

4. Revenue, special allocation funds, the general allocation fund and revenue sharing domesti influence the gross regional product.

\section{RESEARCH METHODOLOGY}

Population. In this study population was all districts / cities in South Sumatra Province. In 2006 through 2013 the district / city as much as 14 to 15 districts / cities with the details in the 2006 and 2007 amount to 14 districts / cities, and by 2008 to 2013 as many as 15 districts / cities. Total population is defined as 15 districts / cities with combined data time series and cross section districts / cities taken from cluster sampling all districts / cities in the region of South Sumatra Province in 2006 through 2013.

Table 4 - Number District / City

\begin{tabular}{|c|c|c|c|c|c|c|c|c|c|c|}
\hline \multirow{2}{*}{ No } & \multirow{2}{*}{ Province } & \multicolumn{8}{|c|}{ Year / No. of districts / cities } & \multirow{2}{*}{ Total } \\
\hline & & 06 & 07 & 08 & 09 & 10 & 11 & 12 & 13 & \\
\hline \multicolumn{9}{|c|}{ The total number of district / city } & 15 & $\begin{array}{l}118 \\
118 \\
\end{array}$ \\
\hline
\end{tabular}

Types and Sources of Data. In a study using a type of quantitative data, the measurement process is a central part in the study because it provides the fundamental connection between empirical observation and mathematical expression of quantitative relationships. In this study the source of the data used is secondary data. Publication of certain data performed by authorized agencies are widely used in this study as the data from Bappenas, Ministry of Finance, Bank Indonesia, Central Bureau of Statistics and other sources that are relevant to this study. 
Analysis method. The analytical method used in this research is quantitative analysis methods that are inferential hypothesis testing. This analysis method aims to produce a finding can be generalized widely in the population area. The analytical tool used is a data panel that incorporates data time range (time series) and data cross (cross section). In this research to facilitate the analysis of the constructed model. Econometric model according Intriligator (1978) is a special pattern on algebraic model of a phenomenon that is stochastic economy which also includes one or more confounding variables. Special pattern or model of the algebra of the econometric model describes the relationship with each other from their respective constituent variables, which consists of the explanatory variables (explanatory variables) and variables endogennya (endogenous variables). Econometric model must meet: (1) the economic criteria or the theoretical expectations (theoretically meaningful), especially concerning the mark (sign) and size (magnitude) of the parameters of simultaneous equations formed, (2) statistical criteria relating to the degree of accuracy (goodness of fit ), and (3) the criteria specifying an econometric estimation has the required properties such as unbiasedness, efficiency, sufficiency and consistency (Koutsoyiannis, 1977).

Specifications Model. The model is an explanatory of the actual phenomena that occur in our daily lives. Model is a quick overview of what is in people's lives. The model is built in this study is an econometric model. Econometric model is a description of the relationship of each of explanatory variables (explanatory variables) against endogenous variable (dependent variables). Specifications model formulated in this study consisted of four equations are built to address issues that have been set. All three models are:

1. Model for the analysis of regional expenditure on education index:

$$
\begin{aligned}
& \text { IPit }=a 0+a 1 B S P D i t \text { a2PDRBit }+++\varepsilon \text { it a3DAUit } \\
& \text { Parameter estimation of the expected: } a 1, a 2, \text { a3 }>0
\end{aligned}
$$

Where: IP = education index; $\mathrm{BSPD}=$ education sector spending; the GDP = gross regional domestic product; DAU = General Allocation Fund.

2. Model analysis of expenditure on the health index:

$$
\begin{aligned}
& \mathrm{IKit}=\mathrm{b} 0+\mathrm{b} 1 \mathrm{BSK} \text { it b2PDRBit }+++ \text { cit b3DAK } \\
& \text { Parameter estimation of the expected: b1, b2, b3>0 }
\end{aligned}
$$

Where: IK = health index; $B S K=$ health sector spending; the GDP = gross regional domestic product; DAK = Special Allocation Fund.

3. Model analysis of the effect of expenditure on human development index:

$$
\begin{aligned}
& \text { C1TBLJit IPMit }=\mathrm{c} 0+++\varepsilon \text { it c2PDRBit } \\
& \text { Parameter estimation of the expected: } \mathrm{c} 0, \mathrm{c} 1, \mathrm{c} 2>0
\end{aligned}
$$

Where: $\mathrm{HDI}=$ human development index; TBLJ = Total expenditure; the GDP = gross regional domestic product. product:

Model analysis of the effect of PAD, DAU, DAK, DBH of the regional gross domestic

$$
\begin{aligned}
& \text { PDRBit }=\mathrm{d} 0+\mathrm{d} 1 \text { PADit } \mathrm{d} 2 \mathrm{DAUit}+++\mathrm{d} 4 \mathrm{DBHitb} \mathrm{d} 3 \mathrm{DAKit} \\
& \text { Parameter estimation of the expected: } \mathrm{d} 0, \mathrm{~d} 1, \mathrm{~d} 2, \mathrm{~d} 3, \mathrm{~d} 4>0
\end{aligned}
$$

Where: The GDP = Gross Regional Domestic Product; the original PAD = Regional Revenue; $\mathrm{DAU}=$ General Allocation Funds; $\mathrm{DAK}=$ Special Allocation Fund; $\mathrm{DBH}=$ Revenue-sharing.

The number of equations formed in the model consists of 4 equations. Left element in the equation is endogeneus variables and elements right is eksogeneus variables. Data processing was performed using a computer software program Eviews version 7 . 


\section{RESULTS AND DISCUSSION}

\section{Research result:}

Education Index. The education index gives a great influence in the increase or decrease in the numbers of human development index. As an important component of the analysis of the education index was included in the study analysis. Index analysis to education during 2006 to 2013 in each district / city can be the following data:

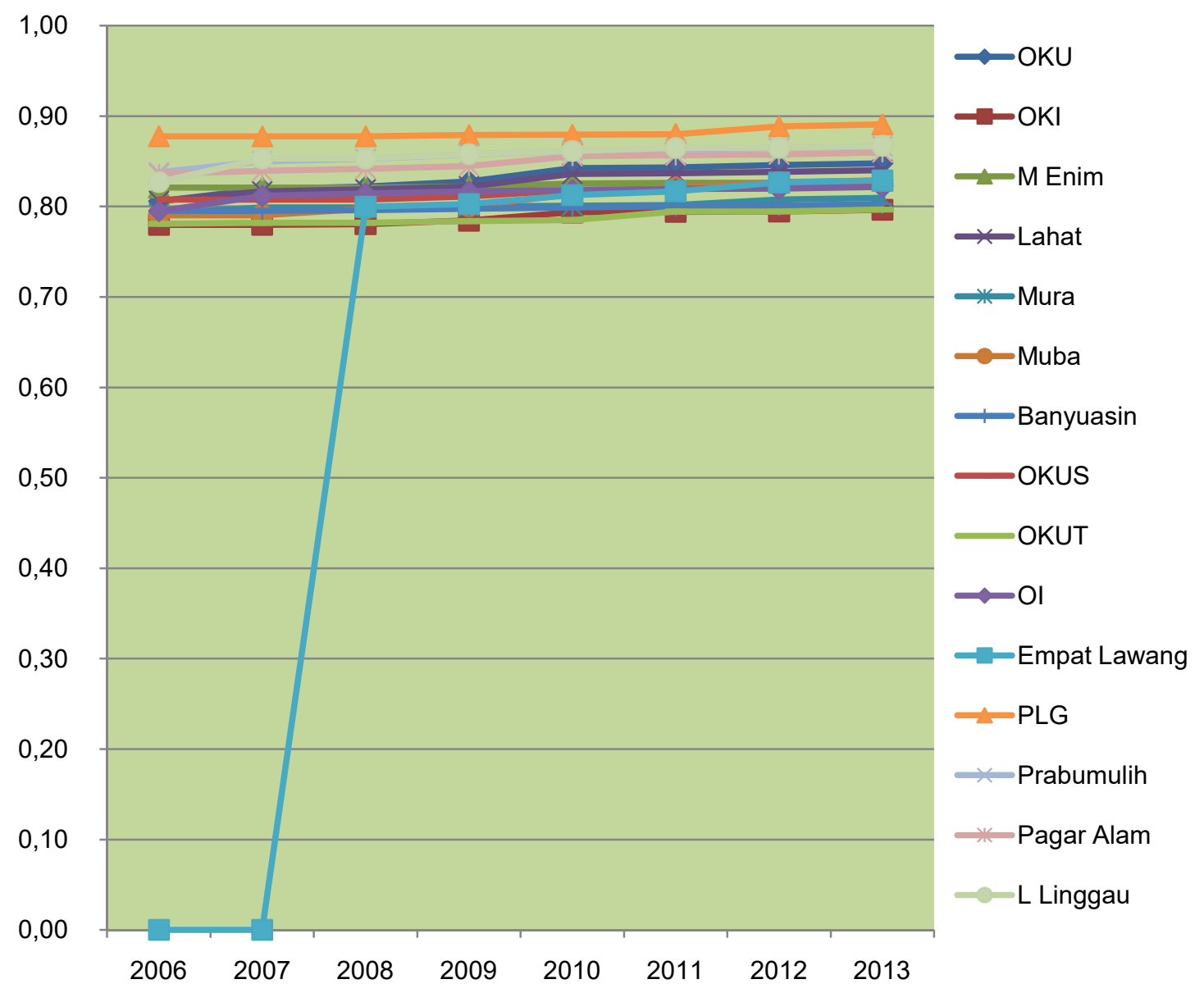

Figure 1 - Education Index Regency / City of South Sumatra province, 2006-2013 Source: Central Bureau of Statistics.

Based on data from Figure 13 are districts in 2006 to 2007 do not have the education index is Empat Lawang. This district not yet have an index of education in the two years is due to the district not been formed in the year. Noting that data to be a tendency on the respective district education index rising trend during the study period, but the upward trend has not shown a significant increase in numbers. From the above data can be ranked on average the highest education index by 0.88 points achieved by Palembang, 0.86 point reached by Prabumulih and Lubuk Linggau and 0.83 point reached by Lahat and Ogan Ulu Ogan.

Health Index. Health Index (IKit) is an index that is formed by the variable of life expectancy $(\mathrm{AHH})$. The higher the life expectancy, the higher the health indices in districts / cities. The health index reflects the average length of a person aged minimal and the average person aged maximum. The average age that a standard minimum is 25 years, while the maximum age of a person according to the target that has been set is for 85 years. The development index of health districts / cities in the province SumSelselama the study period of 2006 to 2013 can be seen in the following figure: 


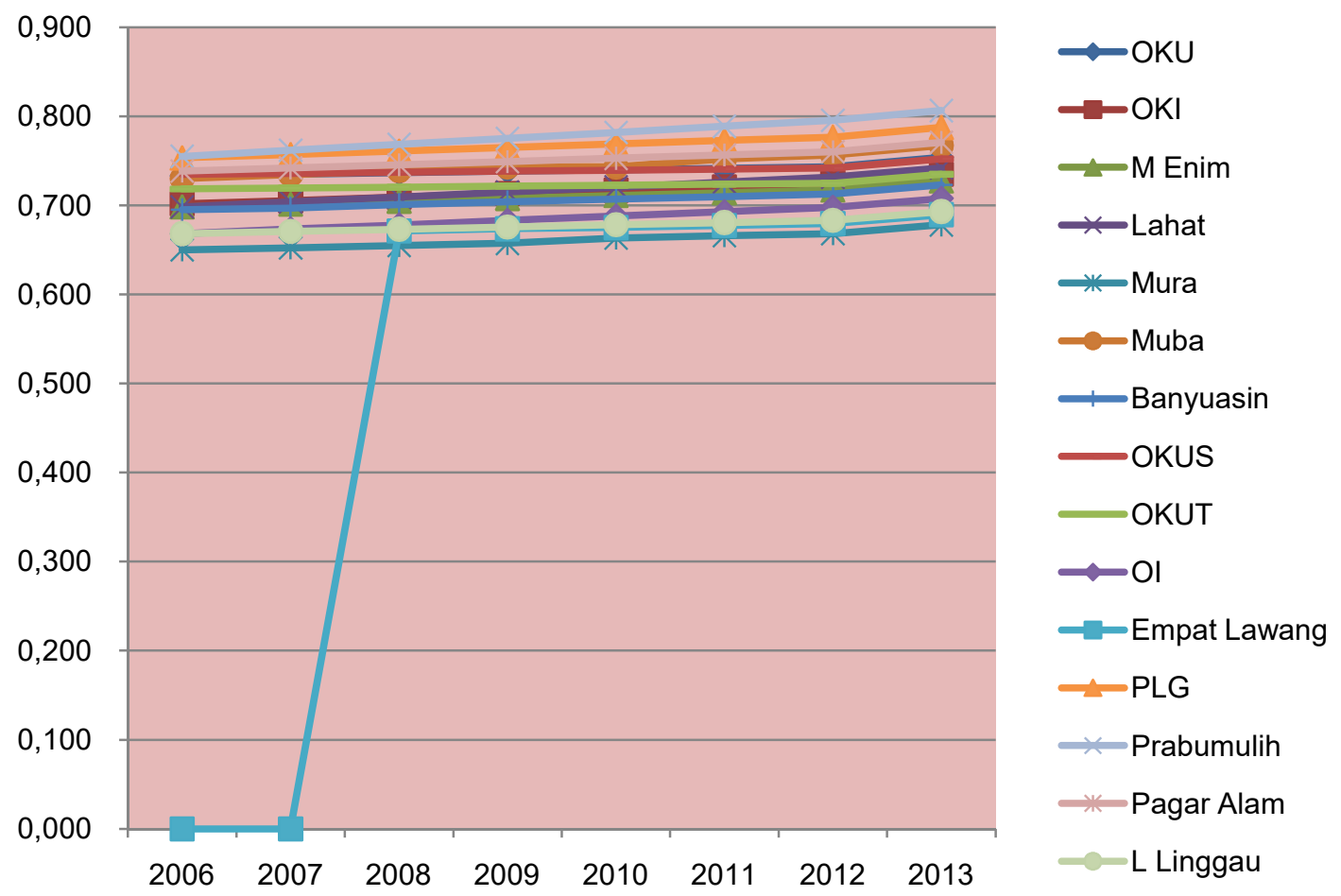

Figure 2 - Health Index Regency / City - Province South Sumatera Province, 2006-2013 Source: Central Bureau of Statistics.

Look at Figure 2 above shows that the index of public health in the districts / cities have shown an increasing trend, but the growth rate has not shown significant improvement of education index. The health index over the study period contained in Prabumulih in 2013 amounted to 0,806 points. The second largest city of Palembang in 2013 amounted to 0.787 points and the third largest is Pagar Alam by 0.771 points. The smallest health index during the study were Musi Rawas with a value of 0.650 points in 2006 . Based on these data can be described health index rating in each district / city as follows:

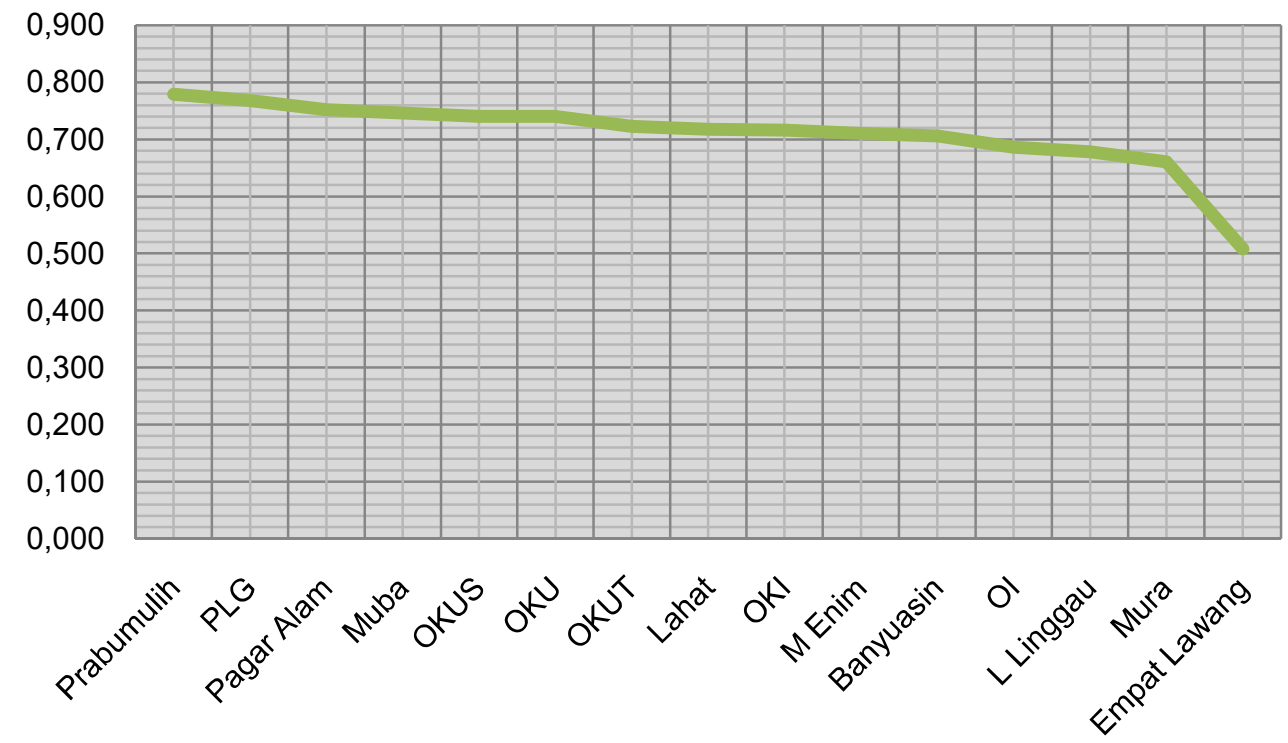

Figure 3 - Average Index Health Office / City of South Sumatra province, 2006-2013 Source: Central Bureau of Statistics. 
The average health index above is developed by the district / city with the largest health index value to Kabuapten / cities with the smallest health index. The average index of the largest health was Prabumulih, then the second largest city of Palembang and is the third largest city of Pagar Alam.

Total Expenditure of Local Government. Total local government expenditure is the total expenditure incurred by the district / city in one year to finance all programs and activities that have been planned in the budget revenue and expenditure of the district / city concerned. Total spending is a combination of all the shopping has been done by the organizational units in the district / city. The figure below shows the total expenditure of district / city during the observation period of the study.

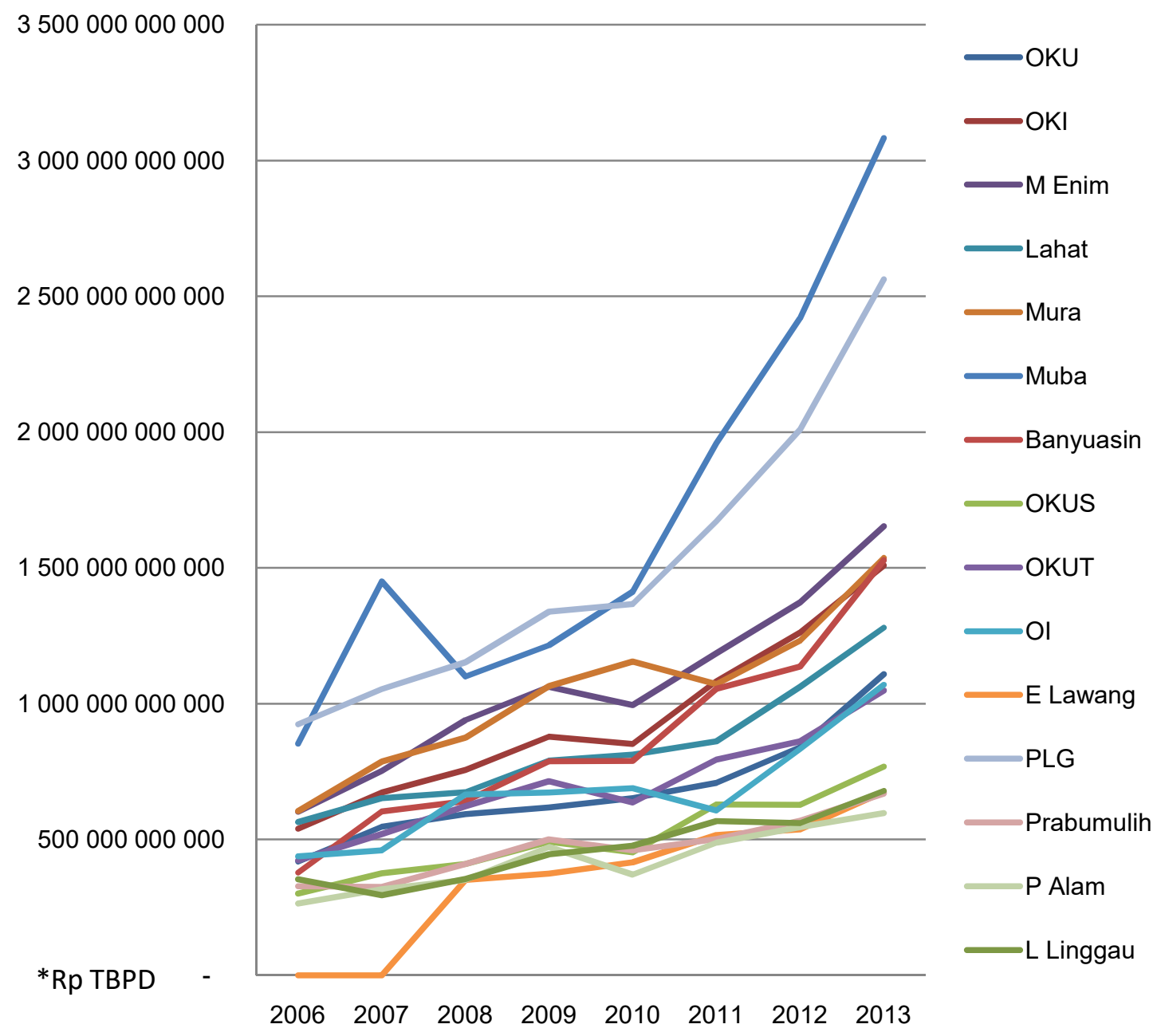

Figure 4 - Total Shopping District / Municipality in South Sumatra province, 2006-2013 Source: Ministry of Finance of the Republic of Indonesia, 2015.

Developments shopping district / city government showed an increase that continues from year to year. The average for all districts / cities total spending showed an improved trend from year to year. Data show that the Musi Banyuasin in the year 2013, total expenditure amounted to Rp.3.083.258.000, -. Total spending is the highest when compared to the district / city the other in South Sumatra province, next Palembang in the same year had a total expenditure of Rp.2.563.209.000, - and a district that has the third highest total expenditure is Muara Enim with a total expenditure of Rp.1.653.570.000,-. The average amount of total spending in 2006 to 2013 from the district / city in South Sumatra province is shown in Figure 5 below: 


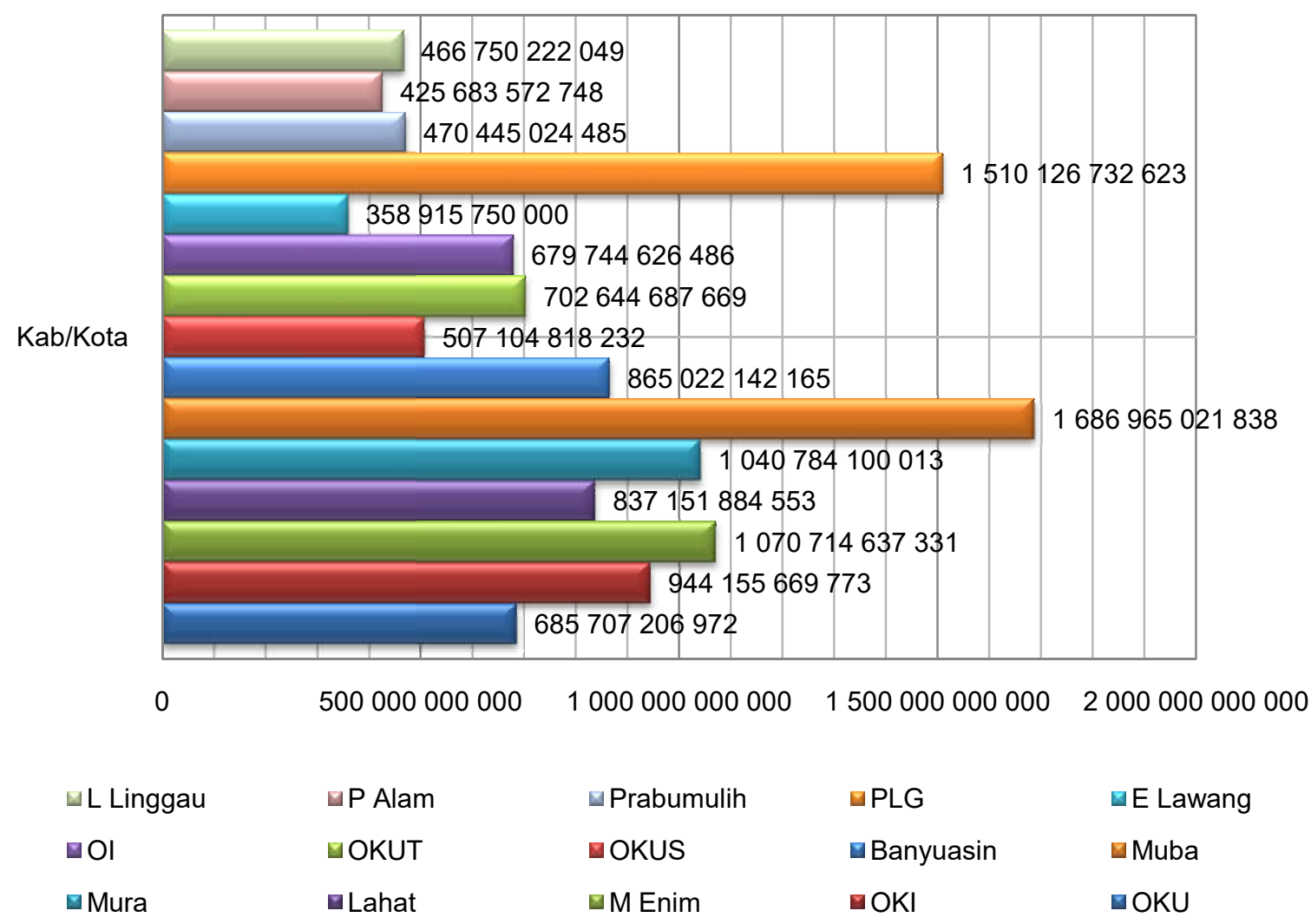

Figure 5 - Average Total Shopping District / Municipality in the South Sumatera Province, 2006-2013 Source: Ministry of Finance of the Republic of Indonesia, 2015.

Noting Figure 5 of the above average total shopping districts / cities in the province SumSelmenunjukkan that Musi Banyuasin, Palembang and Muara Enim has an average expenditure during the study period from 2006 to 2013 the highest among districts / cities.

\section{DISCUSSION OF RESULTS}

General Analysis Model Estimation. After analyzing the data obtained from various sources which have links with the object and subject of research by using four equations, the models presented are the final results after several rounds of refinement and adjustment to the input from various parties. Data were built in this model is the form of panel data, the structural equation has been built based on the data panel, and estimation methods used are data panel estimation method with fixed effect model specifications, common effect or random effect. Program and estimates for the parameters of the four equations comprising explanatory variable parameters are presented in full in Appendix, which is narrated in the section of this chapter. In general the results of analysis of the alleged parameters established above equation has a good value, it appears from the coefficient of determination (R2) substantially in each equation. This suggests that the explanatory variables or predetermined in each model can explain fluctuations endogennya real variable. The research looked at the alleged mark parameters in the model according to the hypothesis, which is based on the theory.

Alleged Parameter Equation. In the following analysis will be described coefficient parameters in each equation. In the first equation will be analyzed the effect of spending on the education sector (BSPDit), regional gross domestic product (PDRBit) and the allocation of funds umu (DAUit) to the improvement of education index. The second equation will be analyzed the influence of the health sector expenditure (BSKit), regional gross domestic product (PDRBit) and special allocation funds (DAKit) to the improvement of the health index (IKit). The third equation will be analyzed the effect of total expenditure (TBLJit) and gross 
regional domestic product (PDRBit) to increase human development index (IPMit). The last equation is analyzed the influence of local aasli income (PADit), general allocation fund (DAUit), a special allocation fund (DAKit) and revenue sharing (DBHit) to increase the gross regional domestic product (PDRBit).

Analysis of the Education Equality Index. The analysis of the equation of education index (IPit) built with exogenous variables education sector expenditure (BSPDit), regional gross domestic product (PDRBit) and the general allocation fund (DAUit). In the early stages do regression to the data needed to determine how to estimate the model.

Based on the test results chow tests conducted for the right model whether common effect or fixed effect. Based on the analysis of test cow tests conducted by comparing the Sum Square Error of the model common effect and Sum Square Error of the fixed effect model in can be calculated $F$ value of 32.7256 points. The value of $F$ table at $5 \%$ by numerator df 14 and 102 denumerator can then $F$ table value of 1.79 point. $F$ count larger than $\mathrm{F}$ table then based on test chow $\mathrm{H} 1$ accepted and considered to use a fixed effect model. Hausman test is then performed to see if the model used using a fixed effect or random effect. By comparing the value of chi square table at df $5 \%$ then can the value of 7.815 points. Hausman statistical value in the can is 19.76 points. Based on these results it is estimated using a fixed effect models. Once can model using a fixed effect estimation then the next normality test. Normality test showed that the data distributed by normal or not normal. In the equation in the health index can point value probability of 0.625662 . This value is greater than $5 \%$. Probability value greater than 0.05 indicates that the normally distributed data and can be used in a statistical test. The results of model estimation using a fixed effect on equality in the education index can result in partial regression that the education sector expenditure (BSPD) has a significant influence on the increase in the index of education in the district / city of South Sumatra province. Values 11.4317 statistic $t$ is greater than $t$ table at a significance level of $5 \%$. Probability value of education sector expenditure variable is 0.0000 which is less than 0.05 means that the variable education sector spending significantly affect the education index.

Variable gross regional domestic product (GRDP) partially also significantly affect the increase in education index with a value of $t$ statistic of 16.59357 point. The value of this statistic $t$ value is greater than $t$ table at a significance level of $5 \%$ and variable degrees of freedom 12. Probability regionaal gross domestic product also showed a smaller number of 0.05 . It can be stated that the regional gross domestic product variables significantly influence the education index. Variable general allocation fund (DAU) has a constant value is negative. This shows that the variable of general allocation funds negatively affect the education index with a value of -0.0967 point. The higher the general allocation fund the education index figures would be lower and vice versa. Partially general allocation fund a significant influence on improving education index with a value of $5.398047 \mathrm{t}$ statistic point. The value of this statistic $t$ value is greater than t table at a significance level of $5 \%$ and variable degrees of freedom 12 . Probability regionaal gross domestic product also showed a smaller number of 0.05 . It can be stated that the general allocation fund significant variable affecting the education index.

In theory should be the general allocation fund is positive affect education index but in the analysis results can reverse phenomenon. This phenomenon may occur due to the general allocation fund is the largest portion is used for personnel expenses or salaries of civil servants. It can also happen phenomenon caused by the number of civil servants were in excess of the maximum needs of the district / city. The advantages of these employees juimlah result in underpayment of salaries of employees coming from the general allocation fund so as to cover the deficit used also for shopping receipts from other funds.

The effect of the provision of salaries to civil servants are expected to spur motipaasi to all citizens to have an awareness of the importance of education and access to a decrease in the illiteracy rate also does not provide maximum results. Phenomenon is the general allocation fund is negative on the index of education can also be caused by the inefficiency of the salary given to local civil servants. Lebbih remuneration of the existing standards by incorporating various allowances that large values can also cause a general allocation fund 
is negative toward education index. Policy implications that can be done by the district / city against the negative influence of the general allocation fund is to rationalize the number of employees in the district / city each so that the general allocation fund in addition be used for personnel expenditure, general allocation fund can also be used for capital expenditure can be a positive influence on the increase in the index of education, especially in South Sumatra.

Taken together the equations built affect the dependent variable with a value of $F$ statistic of 40.98911 point. These statistical $F$ value Leih the value of $F$ table at a significance level of $5 \% \mathrm{~F}$ table is 3,88 point. That is jointly variable bebaas education sector expenditure, gross regional domestic product and the general allocation fund significantly affect the dependent variable education index. Based R2 test which determines the proportion of the total variation in the dependent variable explained by the independent variable in the value of R2 can be adjusted by 0.869009 . This value means that 86.9009 percent of the variation of the dependent variable can be explained by the independent variable. Variations that can not be dijelas by the model is equal to 13.0991 percent. Another variation is explained by other variables other than those contained in the model. Noting the results table fixed effect model estimation also be constant in each district / city as the characteristics of the contribution the district / city to the significant value of the independent variable on the dependent variable.

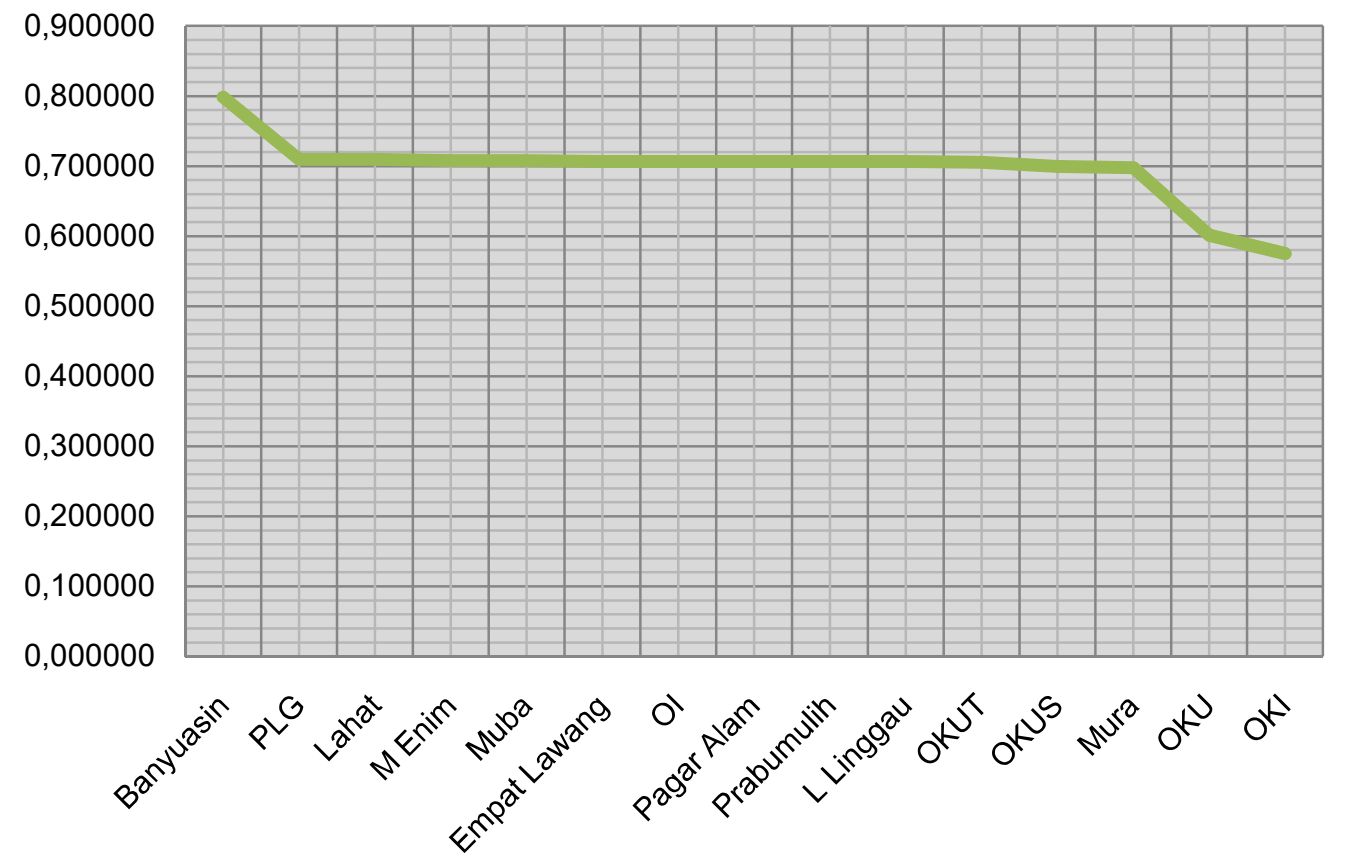

Figure 6 - Contributions district / city Against Education Index

Based on the above picture regencies / cities that most contributed to the variables that can explain these variations are Banyuasin district and the city of Palembang. The lowest contributor are OKU District and the OIC, while other districts / cities contribute relatively the same. Banyuasin the largest contribution to the improvement of education index is based on a constant which is derived due to the district was able to significantly decrease the number of illiterate adults. During the study period of 2006 to 29013 the number of illiterate adults in Banyuasin has decreased by $66.73 \%$.

Analysis of Similarities Health Index. The analysis of the equation of the health index (IKit) built by the exogenous variables of health sector expenditure (BSKit), regional gross domestic product (PDRBit) and special allocation funds (DAKit). In the early stages do regression to the data needed to determine how to estimate the model. 
Based on the test results chow tests conducted for the right model whether common effect or fixed effect. Based on the analysis of test cow tests conducted by comparing the Sum Square Error of the model common effect and Sum Square Error of the fixed effect model in can be calculated $F$ value of 24.7564 points. The value of $F$ table at $5 \%$ by numerator df 14 and 102 denumerator can then $F$ table value of 1.79 point. $F$ count larger than $\mathrm{F}$ table then based on test chow $\mathrm{H} 1$ accepted and considered to use a fixed effect model. Hausman test is then performed to see if the model used using a fixed effect or random effect. By comparing the value of chi square table at df $5 \%$ then can the value of 7.815 points. Hausman statistical value in the can is 23.76 points. Based on these results it is estimated using a fixed effect models. Once can model using a fixed effect estimation then the next normality test. Normality test showed that the data distributed by normal or not normal. In the equation in the health index can point value probability of 0.789525 . This value is greater than $5 \%$. Probability value greater than 0.05 indicates that the normally distributed data and can be used in a statistical test. The results of model estimation using a fixed effect on equality in the education index can result in partial regression that health sector expenditure (BSK) has a significant influence on the increase in the health index in the district / city of South Sumatra province. Statistical t value 3.397312 is greater than t table at a significance level of $5 \%$. Probability value of education sector expenditure variable is 0.0010 which is less than 0.05 means that the variable health sector expenditure incurred by each district / city significantly affect health index. Variable gross regional domestic product (GRDP) partially also significantly affect the increase in education index with a value of $7.758033 \mathrm{t}$ statistic point. The value of this statistic $\mathrm{t}$ value is greater than $\mathrm{t}$ table at $\mathrm{a}$ significance level of $5 \%$ and variable degrees of freedom 12. Probability regionaal gross domestic product also showed a smaller number of 0.05 . It can be stated that the regional gross domestic product variables significantly affect the health index.

Variable Special Allocation Fund (DAK) has a constant value is negative. This indicates that the variable special allocation negatively affect education index with a value of -0.00251 point. The higher the specific allocation of funds, the health index figure would be lower and vice versa. Partially special allocation funds significantly influence the improvement of education index with a value of $4.879099 \mathrm{t}$ statistic point. The value of this statistic $t$ value is greater than $t$ table at a significance level of $5 \%$ and variable degrees of freedom 12 . Probability special allocation funds also showed a smaller number of 0.05 . It can be stated that the special allocation fund significant variable affecting the health index. Variables affecting the special allocation fund index overall health can be caused by use of special allocation funds that have not been targeted. The use of special allocation funds that should be used to increase life expectancy as a component of the health indices are used for programs and activities that have the possibility to not affect the life expectancy of the district / city concerned.

Taken together the equations built affect the dependent variable with a value of $F$ statistic of 106.6629 points. These statistical $F$ value Leih the value of $F$ table at a significance level of $5 \% \mathrm{~F}$ table is 3,88 point. That is jointly variable bebaas health sector expenditure, gross regional domestic product and special allocation funds significantly influence the dependent variable health index. Based R2 test which determines the proportion of the total variation in the dependent variable explained by the independent variable in the value of R2 can be adjusted by 0.937868 . This value means that 93.7868 percent of the variation of the dependent variable can be explained by the independent variable. Variations that can not be dijelas by the model is equal to 6.2132 percent. Another variation is explained by other variables other than those contained in the model. Noting the results table fixed effect model estimation also be constant in each district / city as the characteristics of the contribution the district / city to the significant value of the independent variable on the dependent variable.

Based on Figure 7 above districts / cities that most contributed to the variables that can explain the variations and improvement of education index is Palembang, Muba regency, OKU District and Muara Enim. The lowest contributor are Mura district, Empat Lawang and South OKU. 


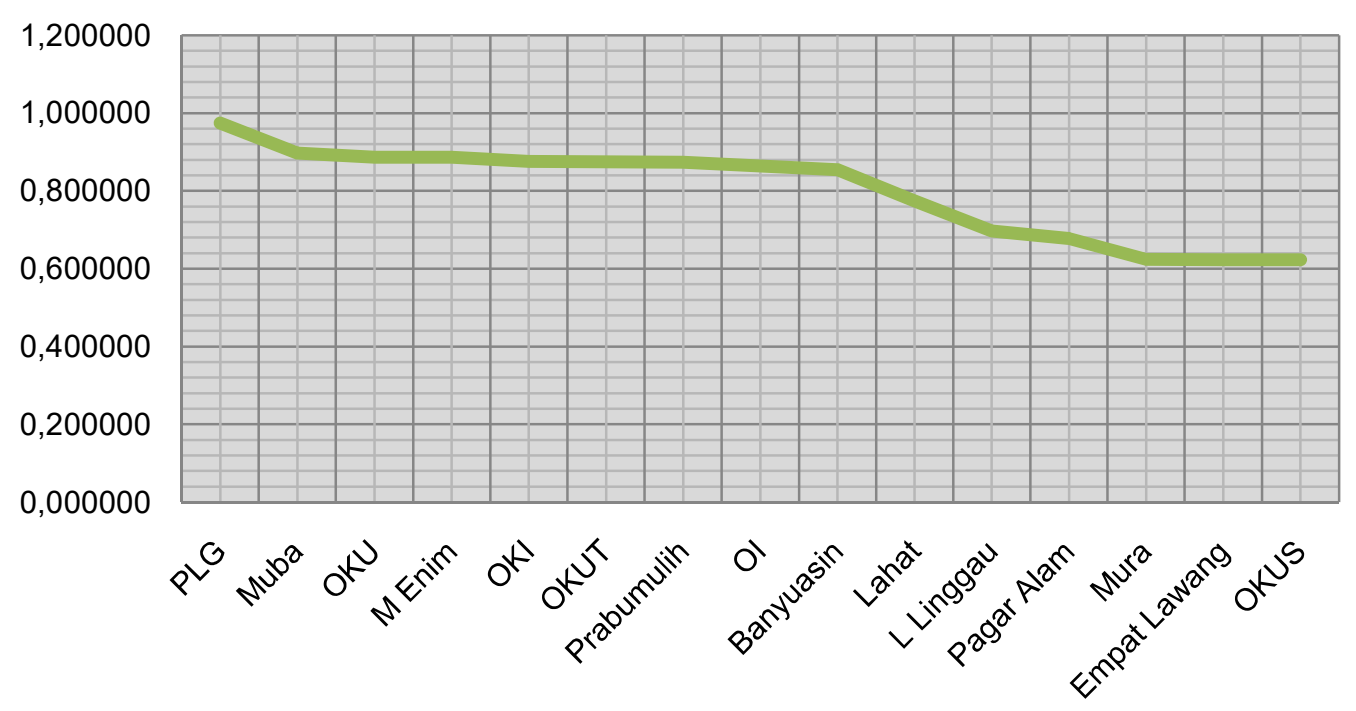

Figure 7 - Contributions district / city Against Health Index

Analysis of Similarities Human Development Index. The analysis of the equation of human development index (IPMit) built with exogenous variables total expenditure (TBLJit) and gross regional domestic product (PDRBit). Based on the analysis of test cow tests conducted by comparing the Sum Square Error of the model common effect and Sum Square Error of the fixed effect model in can be calculated $\mathrm{F}$ value of 5.6547 points. The value of $\mathrm{F}$ table at $5 \%$ by numerator df 14 and 102 denumerator can then $\mathrm{F}$ table value of 1.79 point. $\mathrm{F}$ count larger than $\mathrm{F}$ table then based on test chow $\mathrm{H} 1$ accepted and considered to use a fixed effect model.

Hausman test is then performed to see if the model used using a fixed effect or random effect. By comparing the value of chi square table at df $5 \%$ then can the value of 7.815 points. Hausman statistical value in the can is 14.72 points. Based on these results it is estimated using a fixed effect models. Once can model using a fixed effect estimation then the next normality test. Normality test showed that the data distributed by normal or not normal. On the human development index in the equation can point value probability of 0.589241 . This value is greater than $5 \%$. Probability value greater than 0.05 indicates that the normally distributed data and can be used in a statistical test. The results of model estimation using a fixed effect on the human development index in the equation can result in partial regression that total spending has a significant influence on the increase of the index development in the district / city of South Sumatra province. Value 5.2560762 statistic $t$ is greater than $t$ table at a significance level of $5 \%$. Probability value of education sector expenditure variable is 0.0000 which is less than 0.05 means that the total variable expenditure (TBLJ) issued by each district / city significantly affect human development index. Variable gross regional domestic product (GRDP) partially also significantly affect the increase in education index with a value of $t$ statistic of 13.09415 point. The value of this statistic $t$ value is greater than $t$ table at a significance level of $5 \%$ and variable degrees of freedom 12. Probability regionaal gross domestic product also showed a smaller number of 0.05 . It can be stated that the regional gross domestic product variables significantly affect human development index.

Taken together the equations built affect the dependent variable with a value of $F$ statistic of 175.2942 points. These statistical $F$ value Leih the value of $F$ table at a significance level of $5 \% \mathrm{~F}$ table is 3,88 point. That is jointly variable bebaas total expenditure, gross regional domestic product significantly affect the dependent variable of human development index. Based R2 test which determines the proportion of the total variation in the dependent variable explained by the independent variable in the value of R2 can be adjusted by 0.959074 . This value implies that 95.91 percent of the variation of the dependent variable can be explained by the independent variable. Variations that can not be dijelas by 
models amounted to 4.09 percent. Another variation is explained by other variables other than those contained in the model.

Noting the results table fixed effect model estimation also be constant in each district / city as the characteristics of the contribution the district / city to the significant value of the independent variable on the dependent variable.

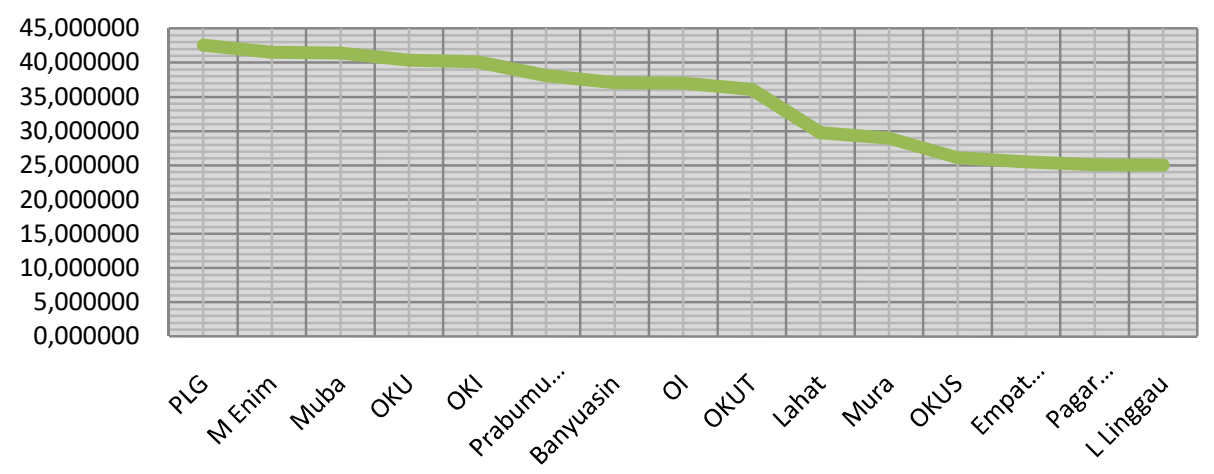

Figure 8 - Contributions district / city Against Human Development Index

Based on the above picture regencies / cities that most contributed to the variables that can explain the variations and increase development index is Palembang, Muara Enim, Muba Regency and Regency OKU. The lowest contributor are Pagar Alam, Empat Lawang and Lubuk Linggau.

Analysis of Gross Regional Domestic Product Equation. The analysis of the equation of regional gross domestic product (PDRBit) is built with an exogenous variable revenue (PADit), general allocation fund (DAUit), a special allocation fund (DAKit) and revenue sharing (DBHit). Based on the analysis of test cow tests conducted by comparing the Sum Square Error of the model common effect and Sum Square Error of the fixed effect model in can be calculated $F$ value of 17.3756 points. The value of $F$ table at $5 \%$ by numerator df 14 and 102 denumerator can then $F$ table value of 1.79 point. $F$ count larger than $F$ table then based on test chow $\mathrm{H} 1$ accepted and considered to use a fixed effect model.

Hausman test is then performed to see if the model used using a fixed effect or random effect. By comparing the value of chi square table at df $5 \%$ then can the value of 7.815 points. Hausman statistical value in the can is 19.987 points. Based on these results it is estimated using a fixed effect models. Once can model using a fixed effect estimation then the next normality test. Normality test showed that the data distributed by normal or not normal. At equality index in the regional gross domestic product can be of value probability of 0.569717 point. This value is greater than $5 \%$. Probability value greater than 0.05 indicates that the normally distributed data and can be used in a statistical test. The results of model estimation using a fixed effect on the equation of regional gross domestic product can result in partial regression that local revenues have a significant effect on the increase in the index development in the district / city of South Sumatra province. 30.70586 statistic $t$ values greater than $t$ table at a significance level of $5 \%$. Probability value of education sector expenditure variable is 0.0000 which is less than 0.05 means that the variable source revenues issued by the respective district / city significantly affect the regional gross domestic product.

Variable general allocation fund (DAU) partially does not significantly affect the increase in regional gross domestic product with a value of $t$ statistics for -1.091596 point. Probability variable general allocation funds also show a number greater than 0.05 . It can be stated that the variable of general allocation funds (DAU) did not significantly affect the regional gross domestic product. Partially special allocation funds have a significant effect on the increase Based on the results table equation analysis on the regional gross domestic product may result DAK have a significant effect on the increase in the gross regional domestic product regencies / cities of South Sumatra province. Statistical t value 2.415678 is 
greater than $t$ table at a significance level of $5 \%$. DAK variable probability value of 0.0175 which is less than 0.05 means that the variable special allocation issued by the respective district / city significantly affect the regional gross domestic product. in the district / city of South Sumatra province. Variable profit sharing fund (DBH) partially significantly affect the increase in regional gross domestic product with a value of $t$ statistic of 13.31120 point. Probability variable general allocation funds also show a number greater than 0.05 . It can be stated that the variable profit sharing fund $(\mathrm{DBH})$ significantly affect the regional gross domestic product.

Taken together the equations built affect the dependent variable with a value of $F$ statistic of 824.2435 points. These statistical $F$ value Leih the value of $F$ table at a significance level of $5 \% \mathrm{~F}$ table is 3,88 point. That is jointly variable bebaas PAD, DAU, DAK and $\mathrm{DBH}$ significantly affect the dependent variable gross regional domestic product. Based R2 test which determines the proportion of the total variation in the dependent variable explained by the independent variable in the value of R2 can be adjusted by 0.992033 . This value means that 99.2033 percent of the variation of the dependent variable can be explained by the independent variable. Variations that can not be explained by the model is equal to 7.967 percent. Another variation is explained by other variables other than those contained in the model. Noting the results table in the fixed effect model estimation can be constants in the district / city as the characteristics of the contribution the district / city to the significant value of the independent variable on the dependent variable.

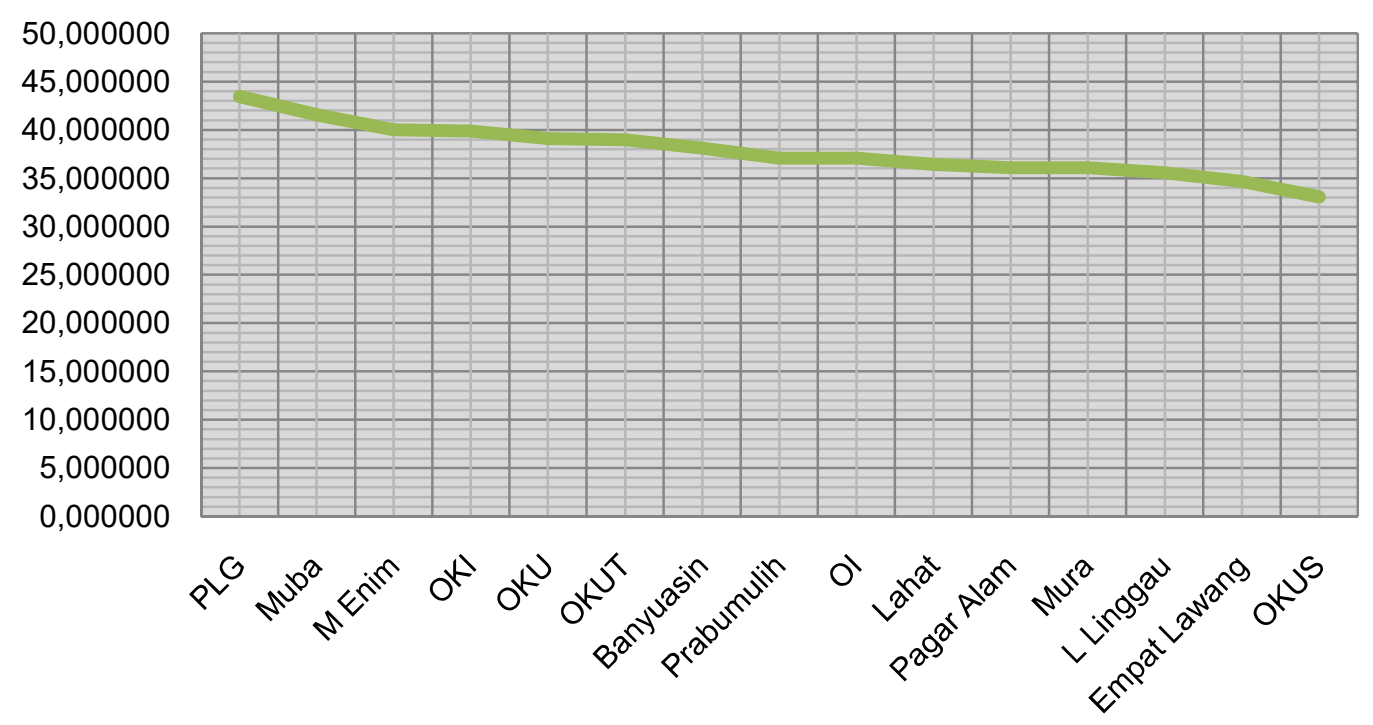

Figure 9 - Contributions district / city Against Gross Domestic Products

Based on the above picture regencies / cities that most contributed to the variables that can explain the variations and an increase in regional gross domestic product is the city of Palembang, Muba District, Muara Enim and OKI. The lowest contributor are Lubuk Linggau Empat Lawang and South OKU District.

\section{CONCLUSION}

The analysis showed partial education sector expenditure (BSPD), GRDP and DAU have a significant effect on the increase in the index of education in the district / city of South Sumatra province. Value $t$ statistic is greater than $t$ table at a significance level of $5 \%$ and a degree of freedom 12. The variable DAU negatively correlated to education index. Taken together the independent variable education sector expenditure, gross regional domestic product and the general allocation fund significantly affect the dependent variable education index. R2 test showed $86.9009 \%$ can be explained by this model. Analysis of the health 
index equation can result in that the partial expenditure health sector (BSK), the GDP and DAK have a significant effect on the increase in the health index in the district / city of South Sumatra province. Value $t$ statistic is greater than $t$ table at a significance level of $5 \%$. DAK negatively correlated to the health index. Taken together the equations built affect the dependent variable with a statistical $F$ value is greater than the value of $F$ table at a significance level of $5 \%$. R2 test which determines the proportion of the total variation in the dependent variable explained by the independent variable in the value of $\mathrm{R} 2$ can be adjusted by 0.937868 . Analysis of the human development index in the equation can be partially the result that the exogenous variables have a significant influence on the increase in the index development in the district / city of South Sumatra province. Value $t$ statistic is greater than $t$ table at a significance level of $5 \%$. Taken together the equations built affect the dependent variable with a statistical $F$ value is greater than the value of $F$ table at a significance level of $5 \% \mathrm{~F}$. Based on the test R2 total variation in the dependent variable explained by the independent variable in the value of R2 can be adjusted by 0.959074 , Analysis of regional gross domestic product equation can result in that partially exogenous variables have a significant influence on the increase in the GDP district / city of South Sumatra province except for the variable DAU. Value $t$ statistic is greater than t table at a significance level of $5 \%$. DAU variable and no significant negative correlation. Taken together the equations built affect the dependent variable with a statistical $F$ value is greater than the value of $F$ table at a significance level of $5 \%$. R2 value which determines the proportion of the total variation in the dependent variable explained by the independent variable in the value of R2 can be adjusted by means 99.20330 .992033 these variations can be explained by this model.

\section{REFERENCES}

1. Abimayu, A. and Megantara, A. (2009). Era Baru Kebijakan Fiskal. Kompas, Jakarta.

2. Akhmad. (2012). Dampak Kebijakan Fiskal Terhadap Perekonomian Kabupaten/Kota di Provinsi Sulawesi Selatan. Unpublished dissertasion. IPB, Bogor.

3. Alisyahbana, A.S. (2000). Desentralisasi Fiskal dan Kebijakan Pembangunan Daerah. Paper presented at Seminar Ekonomi Science Club STIE YPKP.

4. Anand, S. and Sen, A. (2000). The Income Conmponent Of The Human Development Index. Journal Of Human Development, 1(1).

5. Azwardi. (2007). Dampak Desentralisasi Fiskal Terhadap Kinerja Perekonomian Antar Wilayah Di Indonesia. Unpublished dissertasion. Universitas Padjadjaran. Bandung.

6. Badan Pemeriksa Keuangan. (2014). Dana Alokasi Khusus Dalam Perimbangan Keuangan Pusat dan Daerah. www.jdih.bpk.go.id. (Accessed on 1 April 2014).

7. Badan Pusat Statistik. (2014). Statistik Indonesia. Badan Pusat Statistik, Jakarta.

8. Badan Pusat Statistik. (2014). Sumatera Selatan Dalam Angka. Badan Pusat Statistik, Jakarta.

9. Badan Pusat Statistik. (2006-2013). Kabupaten/Kota Dalam Angka. Badan Pusat Statistik, Sumatera Selatan.

10. Bahl, R.W. and Lim F.J. (1998). Urban Publik Finance In Developing Countries. Oxford University Press, Washington.

11. Departemen Dalam Negeri. (2001). Undang-Undang Nomor 22 Tahun 1999 Tentang Pemerintahan Daerah. J \& J Learning, Yogyakarta.

12. (2001). Undang-Undang Nomor 25 Tahun 1999 Tentang Perimbangan Keuangan Antara Pemerintah Pusat dan Daerah. J \& J Learning, Yogyakarta.

13. (2004). Undang-Undang Nomor 32 Tahun 2004 Tentang Tentang Pemerintahan Daerah. $\mathrm{J} \& \mathrm{~J}$ Learning, Yogyakarta.

14. (2004). Undang-Undang Nomor 33 Tahun 2004 Tentang Perimbangan Keuangan Antara Pemerintah Pusat dan Daerah. J \& J Learning, Yogyakarta.

15. Dombusch, R.S.F. and Startz, R. (2004). Macroeconomic. Ninth Edition. McGraw-Hill International Edition, Singapore.

16. Elsye, R. (2013). Desentralisasi Fiskal. Alqaprint, Jatinangor.

17. Kementerian Keuangan Republik Indonesia. (2014). Data Pokok APBN 2006-2012. 
www.anggaran.depkeu.go.id. (Accessed on 21 April 2014).

18. (2014). Leaflet Dana Alokasi Umum. www.djpk.kemenkeu.go.id. (Accessed on 1 April 2014).

19. (2014). Leaflet Dana Alokasi Khusus. www.djpk.kemenkeu.go.id. (Accessed on 1 April 2014).

20. (2014). Leaflet Dana Bagi Hasil SDA. www.djpk.kemenkeu.go.id. (Accessed on 1 April 2014).

21. Koutsoyiannis, A. (1977). Theory Of Econometrics : An Introductory Exposition Of Econometric Methods. McMillan Press Ltd, London.

22. Kumorotomo, W. (2008). Desentralisasi Fiskal; Politik dan Perubahan Kebijakan 19742004. Prenada Media Group, Jakarta.

23. Kuncoro, M. (1995a). Desentralisasi Fiskal di Indonesia-Dilema Otonomi dan Ketergantungan. Prima No.4 Tahun XXIV.

24. Kuncoro, M. (2013b). Metode Riset Untuk Bisnis dan Ekonomi. 4th edition . Erlangga, Jakarta.

25. (2013). Mudah Memahami dan Menganalisis Indikator Ekonomi. UPP STIM YKPN, Yogyakarta.

26. Mungkasa, O. (2014). Desentralisasi dan Otonomi Daerah di Indonesia. Konsep, Pencapaian dan Agenda ke Depan. http://www.academia.edu/2759012 (Accessed on 14 February 2014).

27. Nanga, M. (2006). Dampak Transper Fiskal Terhadap Kemiskinan Di Indonesia; Suatu Analisis Simulasi Kebijakan. Unpublished dissertasion. IPB, Bogor.

28. Nurman. (2015). Strategi Pembangunan Daerah. Rajawali Pers, Jakarta

29. Rahmawati, F. 2008. Desentralisasi Fiskal, Konsep, Hambatan dan Prospek. Bayumedia, Malang.

30. Samuelson, P.A. and Nordhaus, W.D. (1989). Ekonomi. Erlangga, Jakarta.

31. Simanjuntak, R.A. (2003). Kebutuhan Fiskal, Kapasitas Fiskal dan Optimalisasi Potensi Pendapatan Asli Daerah. Working Paper No.5/2003. LPEM Universitas Indonesia.

32. Susetyo, D. (2004). Faktor-Faktor Yang Mempengaruhi Kebutuhan Fiskal Dan Kapasitas Fiskal Dalam Rangka Otonomi Daerah (Studi Empiris Keuangan Daerah Kabupaten/Kota Di Indonesia). Unpublished dissertasion. Universitas Padjadjaran, Bandung.

33. Susiyati, B.H. (2007). Desentralisasi Fiskal Sebagai Upaya Meningkatkan Penyediaan Layanan Publik (Bagi Orang Miskin) di Indonesia. Speech At Inaugural Ceremony As Professor Stay In Economics. Fakultas Ekonomi Universitas Indonesia, Jakarta.

34. Tambunan, T. (2012). Memahami Krisis Siasat Membangun Kebijakan Ekonomi. LP3ES, Jakarta.

35. Todaro, P.M. and Stephen, S.C. (2012). Pembangunan Ekonomi. 11th edition. Erlangga, Jakarta.

36. United Nations Development Program. (2014). Human Development Indeks And Its Component. https://data.undp.org/dataset/Table-1-Human-Development-Index-and-itscomponents/wxub-qc5k. (Accessed on 14 February 2014). 